\title{
THE EFFECT OF CLIMATE CHANGE ON VEGETABLE FARMERS IN PEST CONTROL DECISIONS: CASE STUDY IN BOMBALI (SIERRA LEONE) AND BEYPAZARI (ANKARA) DISTRICTS
}

\author{
Patrick KARGBO \\ Department of Plant Protection, Graduate School of Natural \& \\ Applied Sciences, Ankara University, Turkey \\ DOI: https://doi.org/10.51193/IJAER.2021.7405
}

\section{ABSTRACT}

The study was the effect of climate change on vegetable farmers in their pest control decisions (Case study Sierra Leone (Bombali District) and Turkey (Beypazari District). With such the specific objectives were; to identify the new situation caused by climate change in pest control activities, to identify the factors affecting farmer decisions making process on pest control, and also the Perception of vegetable farmers on the causes of climate change in pest control activities. Purposively the communities were selected and the study research design was exploratory, focused on exploring the emergence of themes from respondent data, collected and transcribed via structured interviews. The household head were selected purposively. The study revealed that $(65 \%)$ of the total targeted population are male and $(35 \%)$ are female and also of the fifty (50) vegetable farmers interviewed in Sierra Leone (Bombali District), (35\%) of the population does not receive training on pest management and $(45 \%)$ of the total population in Turkey (Beypazari District) received training on pest management from Turkey. The majority of the vegetable farmers have managed vegetable production for six (6) years now. They have also practiced crop rotation and intercropping. Most of the vegetable farmers have heard about climate change and the main source is mass media. (70\%) of the farmers interviewed within the two countries believe climate change is due to human activities.

This study recommends that vegetable farmers in Sierra Leone should receive training on pest management. In addition, alternative pest control methods should be made available to vegetable farmers to avoid the negative effects of pesticides. And also collaborative efforts from stakeholders in Turkey and Sierra Leone to create adequate awareness on the use ofpesticide.

Keywords: Vegetable crops, climate change, Pest control decisions, temperature, Global 
International Journal of Agriculture and Environmental Research

ISSN: 2455-6939

Volume: 07, Issue: 04 "July-August 2021"

warming, fungicides, pesticides, household, income, crop rotation.

\section{INTRODUCTION}

The world's vegetable crop farmers are challenged with safe, growing, and nutritious food for the rapidly increasing global population in the face of the new change in climate and pest pressures (Bhardwaj, 2012). To enable vegetable farmers to continue to produce highly nutritious crops, they need to have access to appropriate knowledge on pest control, as well as knowledge on climate change.

Climate change in general may be a change in a situation that means various parameters in terms of its climatic appearances (Ayyogari, Sidhya, and Pandit, 2014). Some of these climatic parameters are relativity humidity, temperature, precipitation, and atmospheric gases composition etcetera. It can also be referred to as a change in weather conditions over time depending on the factor. According to Schneider et al (2007), the vulnerability to climate change situation is the degree to which this situation is unable to survive with the radical impacts of climate change. Vegetable crops are a rich source of protein, vitamins, carbohydrates, and salts (Bhardwaj, 2012). The increased health awareness to rural farmers on vegetable crops is now becoming one integral part of the average household's daily meals in Sierra Leone and Turkey. Also, the rapid increase in population growth rate has ignited a high demand for basic dietary for vegetable crops.

The change in climate conditions will pose a negative fell back on vegetable crop production and pest control decisions; consequently which also affect the food supply. The problems of climate change are extreme events that very difficult most time to predict which alter pest control decisions by vegetable farmers. Some of these climate changes that affected vegetable farmer's decisions are the erratic rainfall patterns and the rapid unpredictable high temperature spells consequently affected crop growth rate and increases the number of pests. Developing countries such as Sierra Leone and Turkey were particularly vulnerable. The shifts in the ecology, land degradation, and agro-economic areas etcetera, makes it difficult to cultivate the traditional way.

Climate change poses significant challenges on pest control decisions and negative impacts upon the present vegetable crop production. There is mounting evidence that vegetable farmers in developing countries are experiencing new situation on climate variability which has affected their pest control decisions some of this climate change variability is extreme temperature and precipitation that is linked to increased greenhouse gas emission.

Notwithstanding, the new situation of climate change regards its physiological and biochemical changes has influenced the pest control decision, pathogen mitigation, the ecology appearance 
which has led the development of plant diseases (Khan, 2012).

The change in physiological in climate in plants may alter the farmer's pest control decisions regarding climate change perspective, the resistance to any disease may be overcome quickly because of the change in the climate. Fungicide and bactericide efficiency in pests increased moisture and temperature etc. Climate change most time makes vegetable farmers finding it very challenging to decide on pest control and also it ignited the contact fungicides on crops. Sierra Leone, Bombali District is characterized by grassland and open-bush. Rice, sweet potatoes and cassava are the staple food crops while groundnuts, peppers etcetera comprise the main cash/non-staple crops. The land in Bombali district is suitable for livestock rearing. The total number of people food insecure in Bombali District is 132,322 (MAFFS) and the percentage of household food insecure (severe and moderate) is $25.5 \%$ and Turkey (Beypazari District), the most famous local food in Beypazari district is Kurusu, a traditional long-lasting pastry. The fertile soil of the region makes it produce nearly $60 \%$ of Turkey's carrots, as well as lettuce, green onion, and spinach farming.

\title{
STATEMENT OF THE PROBLEM
}

Sierra Leone and Turkey vegetable farmers have faced a lot of challenges in terms of pest control decisions because of climate change in such countries.

There are very ambitious associated recently in these countries because of inadequate knowledge on the effect of climate change and pest control alternative decisions. The problem facing recently is the higher temperatures from global warming and the increase of sugars in some leaves and lower nitrogen content these has an advanced effect on pest control decision because these can also increase the damage caused by some insects and also help the integration of new pest.

Another possible effect of climate change that needs to be taken into account that affected pest control decision is a warmer temperature which also lowers the effectiveness of some fungicides and pesticides in pest control.

\section{AIM AND OBJECTIVES OF THE RESEARCH}

\begin{abstract}
Aim
The aim of this study is the effect of climate change on vegetable farmers in pest control decisions (Case study Sierra Leone (Bombali district) and Turkey (Beypazarı, Ankara).
\end{abstract}




\section{Objectives of the study}

Objectives of the study are as follows:

1. Identify new situation caused by climate change in pest control activities.

2. To identify the factors affecting farmer decisions making process on pest control

3. Perception of vegetable farmers on the causes of change in climate in pest control activities

\section{Research Questions of the study}

The study researched some of the following questions:

- What is the new situation caused by climate change in pest control activities?

- What are the factors affecting farmer decisions making process on pest control?

- What is the Perception of vegetable farmers on the causes of change in climate in pest control activities?

\section{Justification}

The challenges of climate change on vegetable farmers in pest control decisions is caused due to higher temperatures that hasten the life cycle of many pests, multiplying their birth rate consequently and also increasing the infection pressure. The increase in the number of pathogens due to climate change will eventually lead to unprecedented opportunities for pests which also affected the farmer pest control decision.

\section{Scope}

This research was conducted mainly within Sierra Leone (Bombali district) and Turkey (Ankara province, Beypazari district) because there is a huge number of vegetable farmers in such areas and such districts are famous in terms of vegetable production. According to the study, the following was of a target to identify the new situation caused by climate change in pest control activities, to identify the factors affecting farmer decisions making process on pest control, and perception of vegetable farmers on the causes of change in climate in pest control activities.

\section{Limitations}


The challenges faced in the study are numerous, to name but a few, these will include constraints in terms of finance, time, and logistics, as well as difficulties in accessing information.

There was also be a constraint in transportation from the researcher's residence to the case study area during the research period, there is also a communication problem with the farmers. However, various measures are being put in place by the researcher to minimize the obstacle that emerged to reach the goal of the project.

Therefore, the researcher's result cannot be taken absolutely. Notwithstanding that, the researcher will of the view that the result will be adequate and useful for the purpose of this study.

\section{MATERIALS AND THE METHODS}

\section{Introduction}

The materials and the methods adopted in this research comprise the research design, the study area, the population, the sample and sample procedure, Data Collection, research instrument, Administration of the Questionnaire and Data Processing

\section{Description of the study area}

(Bombali district, Sierra Leone)

Bombali District is on the Northern Province of Sierra Leone and have its capital call Makeni. Bombali district comprises of the Temne and Limba as the most populated ethnic groups. Their main occupation is farming and trading. This zone is characterized by grassland and open-bush approximately $90 \%$ of the cattle in Sierra Leone are found in the Northern Province, predominantly in Bombali and Koinadugu Districts. About 200000 hectares approximately of savannah woodlands annually. Rice, sweet potatoes and cassava are the staple food crops while groundnuts, peppers etcetera comprise the main cash/non-staple crops. The total number of people food insecure in Bombali is 132,322 (MAFFS, 2018) and the percentage of household food insecure (severe and moderate) is $25.5 \%$.

Turkey (Ankara provinces, Beypazari District)

Beypazarı district is a district of Ankara Province of Turkey, with approximately $100 \mathrm{~km}$ west of Ankara city. According to the recent census, the population of Beypazari district is 46,493. Beypazari District Turkey has been a settlement since the ancient times and also holds symbols of ancient traditions with rich natural resources and historical, according to UNESCO report. The 
district has diverse local food, and natural sources.

\section{Research Design}

The study research design was exploratory, focused on exploring the emergence of themes from respondent data, collected and transcribed via structured interviews. The approach to the study was exploratory to gain a deep understanding of climate change on vegetable farmers in pest control decisions (Case study Sierra Leone (Bombali District) and Turkey (Beypazari District)). Leedy and Ormrod (2015) contend that when little is known about a topic and there is inadequate information and unknown variables at play, a qualitative study can assist in the identification of what is important and needs to be studied. The research design used was non-experimental.

\section{Source of Data}

The work was largely based on primary and secondary data. Primary data was sourced from the vegetable farmers. On the other hand, secondary data refers to data which has already been collected and analyzed by someone else.

\section{The Population, sample Size and Sampling Procedure}

\section{Population}

This comprises vegetable farmers in Sierra Leone (Bombali District) and Turkey (Beypazari District, Ankara). 134 existing vegetable farmers in Bombali District (MAFFS Bombali District, Sierra Leone registered vegetable farmers 2021) and 1079 producer in Beypazari District (Ministry of Agriculture and Forestry Turkey, farmers registration system 2020 data).

\section{Sample size}

The target sample size was 100 farmers in Bombali District and Beypazari District in selected chiefdoms that are engaged in large scale vegetable farming. Of the 134 existing vegetable farmers in Bombali District (MAFFS Bombali District, Sierra Leone registered vegetable farmers 2021) fifty (50) were selected randomly and also out of 1079 producer in Beypazari District (Ministry of Agriculture and forestry turkey, farmers registration system 2020 data ) fifty (50) farmers were selected randomly.

\section{Sample procedure}

A purposive sampling technique was use to select the vegetable farmers (which is 100 farmers) as a sample for the survey. 


\section{Data Collection Methods}

The data was collected using survey, which comprised face-to-face interviews. Interviews were conducted in Krio and Turkish in person. The researcher and his team took shorthand notes of the conversation with each respondent to reconstruct the interview as accurately as possible as fact. 30 minutes were allocated for each questionnaire.

\section{Research Instruments}

A research questionnaire and interview guide were designed to facilitate interviews and the questionnaire was self-administered by the researcher and his three (3) other enumerators to individuals master farmers. The questionnaire used close and open- ended questions. Interview guide was used to guide the researcher and a notebook was used for note-taking. Following the interview including the primary source was gathered, reviewed, and then analyzed.

\section{Administration of the Questionnaire}

Interviews were organized with the vegetable farmers who were randomly selected and then the questionnaire was explained and administered to them since most of them could not read and understand well. The researcher then interviewed the farmers and conducted individual face-toface interviews.

\section{Data Processing}

The researcher investigated various data analysis software before settling for Excel professional software for quantitative, qualitative, and mixed methods of data analysis. A general strategy for organizing and analyzing qualitative data includes the identification of preliminary categories helpful to the coding of the data (Leedy \& Ormrod, 2015). The researcher drafted such a preliminary set of data categories and subcategories, listing general themes identified throughout the transcription and data editing process, as pertain to the research objectives. The researcher then used the SPSS software, analysis step to code interview data by respondent and research question, and by each category and subcategory from the preliminary table. Coding increased the efficiency with which the researcher was able to find, access, and reference respondent data.

The statistical analysis is a keyword frequency search tool, to efficiently code categories and subcategories to efficiently establish data-driven themes as Dominant, Semi- Dominant, Important or Inconclusive - memo-coded by respective themes. The researcher presented the data in a tabular format and used charts displaying frequencies, percentages, and means to explain the relevant allocation of response on all the variables. Although it was planned, no 
statistical analysis could be done due to the lack of enough discrimination in the variables.

\section{Summary and Conclusions}

Chapter 3 outlined the study research design and methodology, including an explanation regarding why an exploratory methodology was the most appropriate and best-suited approach for the research problem. From the data I cannot do any statistical comparison, because of the nature of the questionnaire, but for joint paper, I can do statistical comparison.

\section{RESEARCH RESULTS}

\section{Introduction}

The research results from the data analysis process outlined in Chapter 3. As detailed in this section, the researcher drafted a preliminary set of data categories and subcategories identified throughout the transcription and data editing process, as they pertain to the research objectives and questions as seen below in 4.2 Presentation of Results, lists the preliminary categories and subcategories. The researcher used Excel Microsoft to code all interview data firstly by the respondent, then by the research question, and thereafter by each identified preliminary categories and subcategories.

Strategy and approaches for analyzing qualitative data are less prescriptive than analysis of quantitative data, and generally involve a greater reliance on inductive reasoning processes. The researcher observes situations, events, or concepts in the data and imposes specific meaning on these via some form of coding with conclusions drawn thereafter. This flexibility and openmindedness are beneficial, though also increases the difficulty for a researcher to analyze the data with total objectivity. For this reason, a researcher should continuously acknowledge, to self and others that attitudes and beliefs may inevitably creep in, biasing observations and interpretations (Leedy \& Ormrod, 2015).

\section{Presentation of Results}

One hundred (100) vegetable farmers were selected from Sierra Leone and Turkey, fifty (50) for each country, who were all considered as master farmers who mostly engage in massive farming within the specific district. The interview lasted for 30 minutes with each master farmer.

The sample was selected according to the calculated quota, being representative of the entire vegetable farmers in Sierra Leone (Bombali district) and Turkey (Beypazari district). Four research assistants were recruited to conduct this survey regards the time agreed with the vegetable farmer to complete the interview. 
The researcher asked questions to gain insight and perspective from the vegetable farmers regarding their perceptions and understanding regarding climate change on vegetable farmers in pest control decisions following by identify the new situation caused by climate change in pest controls activities, identify the factors affecting farmer decisions making process and perception of farmers on the causes of climate change in pest control activities. The following question(s) were asked of vegetable farmers to gain deeper insights into their perceptions.

\section{Demographic characteristics of farmers in Bombali district (Sierra Leone) and Beypazari District (Turkey)}

The Demographic characteristics include household head, gender, Age, formal education, and marital status. For these previously compiled factors of demographic, the diagrams show the percentages of participation in the survey among various demographic.

\section{Household head}

Table 4.1 household head

\begin{tabular}{|l|l|l|l|}
\hline \multirow{2}{*}{ Country } & \multicolumn{2}{|l|}{ House heads } & Total (\%) \\
\cline { 2 - 4 } & Yes & No & \\
\hline Sierra Leone & 45.0 & 5.0 & 50.0 \\
\hline Turkey & 48.0 & 2.0 & 50.0 \\
\hline Sum total & 93 & 7 & 100 \\
\hline
\end{tabular}

Table 4.1 shows the household heads for Sierra Leone (Bombali District) and Turkey (Beypazari District), respectively

Figure 4.1 illustrates the percentage of house heads and non-house heads farmers in Bombali district (Sierra Leone) and Beypazari District (Turkey). A total of 100 farmers were interviewed within the two countries (50) vegetable farmers from Sierra Leone (Bombali District) and (50) from Turkey (Beypazari District)) respectively. With respect to the (50) vegetable farmers interviewed in Sierra Leone (Bombali District), (45\%) of them are house heads while $(5 \%)$ are non-house heads. Likewise in Turkey (Beypazari District), out of (50) of farmers interviewed, $(48 \%)$ are house heads while $(2 \%)$ are non-house Heads.

From the data, this shows that there are more household head in Beypazari District (Turkey) than Bombali District (Sierra Leone). 
Percantage of house heads and non house heads farmers in Bombali District (Sierra Leone)

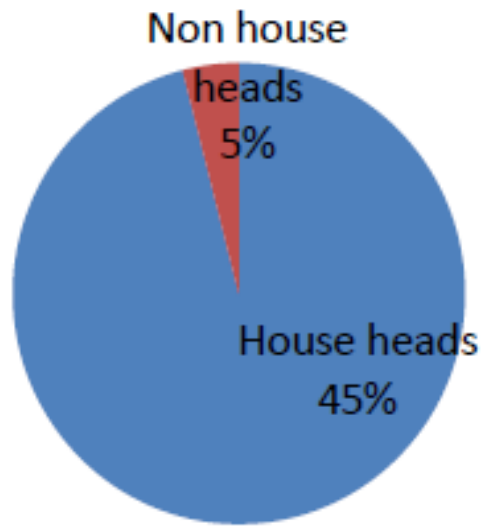

Percantage of house heads and non house heads farmers in Beypazari District (Turkey)

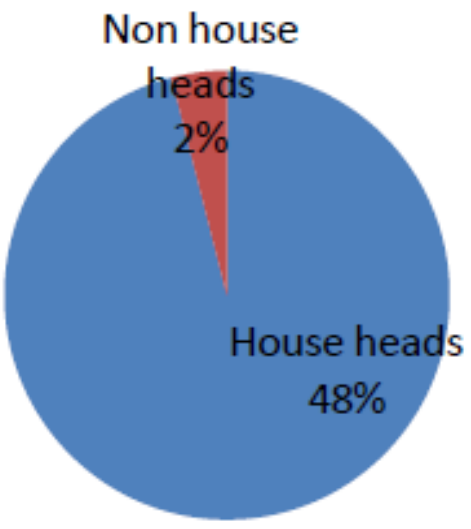

Figure 4.1: above illustrates the percentage of house heads and non-house heads farmers in Bombali District (Sierra Leone) and Beypazari District (Turkey) 


\section{Gender}

Table 4.2 Gender

\begin{tabular}{|l|l|l|l|}
\hline Country & Male & Female & Total (\%) \\
\hline $\begin{array}{l}\text { Sierra } \\
\text { Leone }\end{array}$ & 30 & 20 & 50 \\
\hline Turkey & 35 & 15 & 50 \\
\hline $\begin{array}{l}\text { Sum } \\
\text { Total }\end{array}$ & 65 & 35 & 100 \\
\hline
\end{tabular}

Figure 4.2 shows the percentage of male and female farmers interviewed in Bombali (Sierra Leone) and Beypazari District (Turkey) respectively. A total of 100 farmers were interviewed, (50) from Sierra Leone (Bombali District) and (50) from Turkey (Beypazari District). with regards to the (50) vegetable farmers interviewed in Bombali District (Sierra Leone), (30\%) are male while (20\%) are female. Considering the (50) vegetable farmers interviewed in Beypazari District (Turkey), (35\%) are male while (15\%) are female.

From the analysis, this show that there are more male vegetable farmers in Baypazari District (Turkey) than Bombali District (Sierra Leone) and also there are more female vegetable female farmers in Bombali District (Sierra Leone) than Beypazari District (Turkey). 

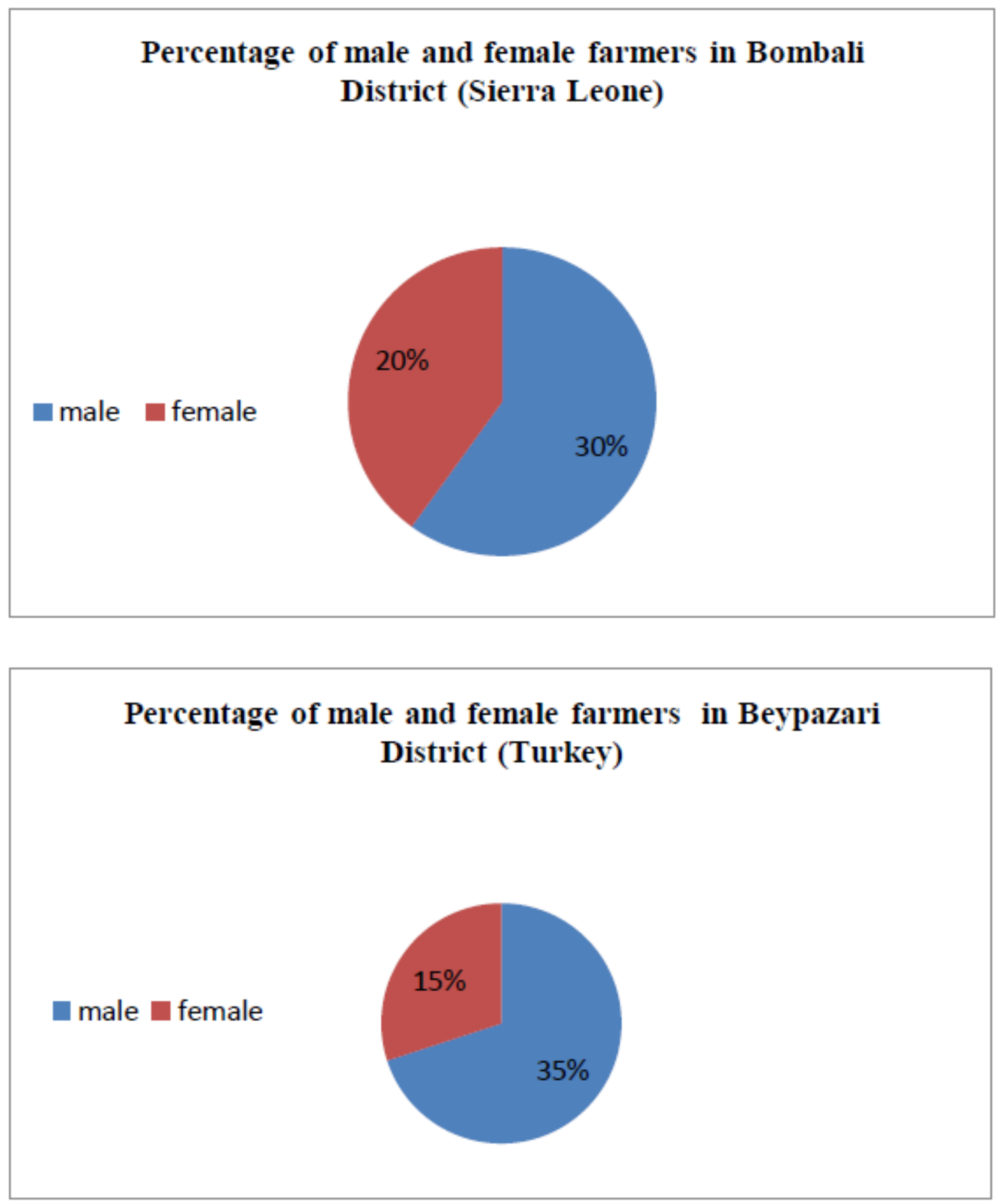

Figure 4.2 above shows the percentage of male and female farmers interviewed in Bombali District (Sierra Leone) and Beypazari District (Turkey) 
Table 4.3 Age

\begin{tabular}{|l|l|l|l|l|l|l|}
\hline \multirow{2}{*}{ Country } & \multicolumn{4}{|l|}{ Age brackets (years) } & Total \\
\cline { 2 - 7 } & $\mathbf{1 8 - 2 8}$ & $\mathbf{2 9 - 3 8}$ & $\mathbf{3 9 - 4 8}$ & $\mathbf{4 9 - 5 8}$ & $\mathbf{5 9 - 6 8}$ & \\
\hline $\begin{array}{l}\text { Sierra } \\
\text { Leone }\end{array}$ & 7 & 8 & 18 & 14 & 3 & 50 \\
\hline Turkey & 8 & 7 & 14 & 10 & 11 & 50 \\
\hline Sum total & 15 & 15 & 32 & 24 & 14 & 100 \\
\hline
\end{tabular}

Figure 4.3 illustrate age bracket of vegetable farmers interviewed in Bombali District (Sierra Leone) and Beypazari District (Turkey). However, Out of the (50) vegetable farmers interviewed in Sierra Leone (Bombali District), (7\%) fall within the age bracket (18-28 years), (8\%) fall within the age bracket (29-38years), (18\%) fall within the age bracket (39-48 years), and (14\%) within (49-58 years) while (3\%) are within (59-68 years) respectively. Similarly to Turkey (Beypazari District), out of (50) vegetable farmers interviewed, (8\%) are within (18-28 years), (7\%) fall within the age bracket (29-38 years), (14\%) are within the age bracket (39-48 years), $(10 \%)$ are within (49-58 years) while (11\%) fall in the age bracket (59-68 years).

From the analysis there are more youth that engage in vegetable farming in Bombali District (Sierra Leone) than Beypazari District (Turkey).

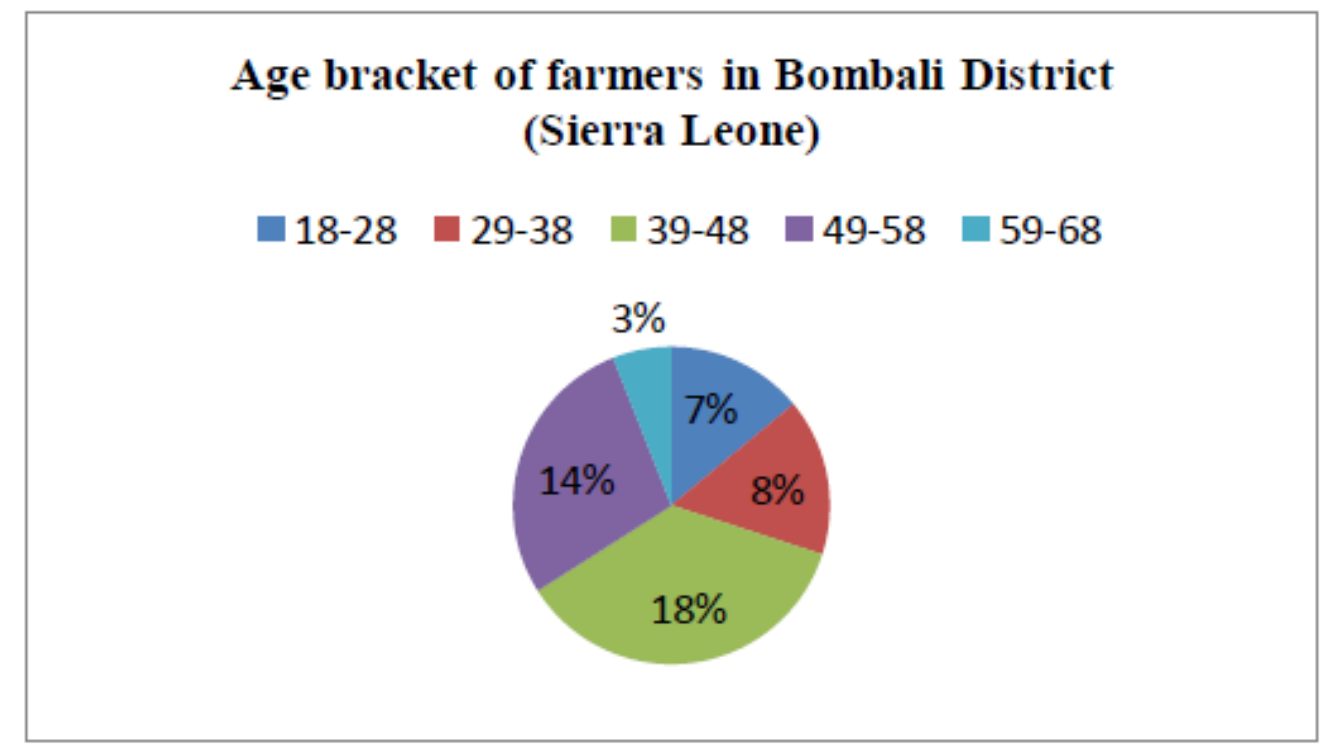




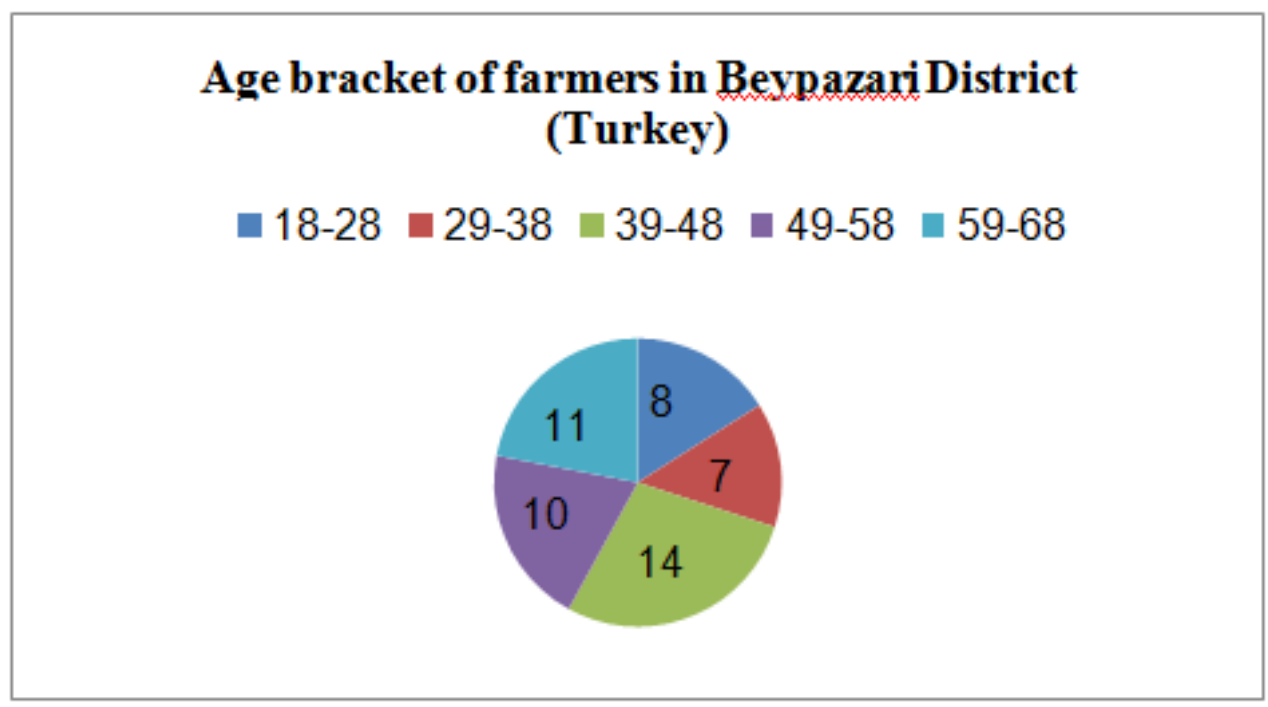

Figure 4.3 above indicates age bracket of farmers interviewed in Bombali District (Sierra Leone) and Beypazari District (Turkey)

\section{Marital status}

Table 4.4 Marital status

\begin{tabular}{|l|l|l|l|l|l|}
\hline Country & Marriage & Single & Divorced & Window & $\begin{array}{l}\text { Total for each } \\
\text { country }\end{array}$ \\
\hline $\begin{array}{l}\text { Sierra } \\
\text { Leone }\end{array}$ & 30 & 0 & 15 & 5 & 50 \\
\hline Turkey & 40 & 0 & 5 & 5 & 50 \\
\hline TOTAL & 70 & 0 & 20 & 10 & 100 \\
\hline
\end{tabular}

Figure 4.4 shows the marital status of famers in Bombali District (Sierra Leone) and Beypazari District (Turkey). Considering the marital status of Vegetable farmers. Out of the (50) vegetable farmers interviewed in Sierra Leone (Bombali District), (30\%) are married, (15\%) have divorced while $(5 \%)$ are widows. No farmer that is single was interviewed. Similarly for Turkey (Beypazari District), (40\%) of the farmers interviewed are married, $(5 \%)$ have divorced while $(5 \%)$ are widows. No farmer that is single was interviewed.

From the data, there are more married vegetable farmers in Turkey (Beypazari District) than Sierra Leone (Bombali District) and also there are more divorced vegetable farmers in Sierra 
International Journal of Agriculture and Environmental Research

Leone (Bombali District) than Turkey (Beypazari District)
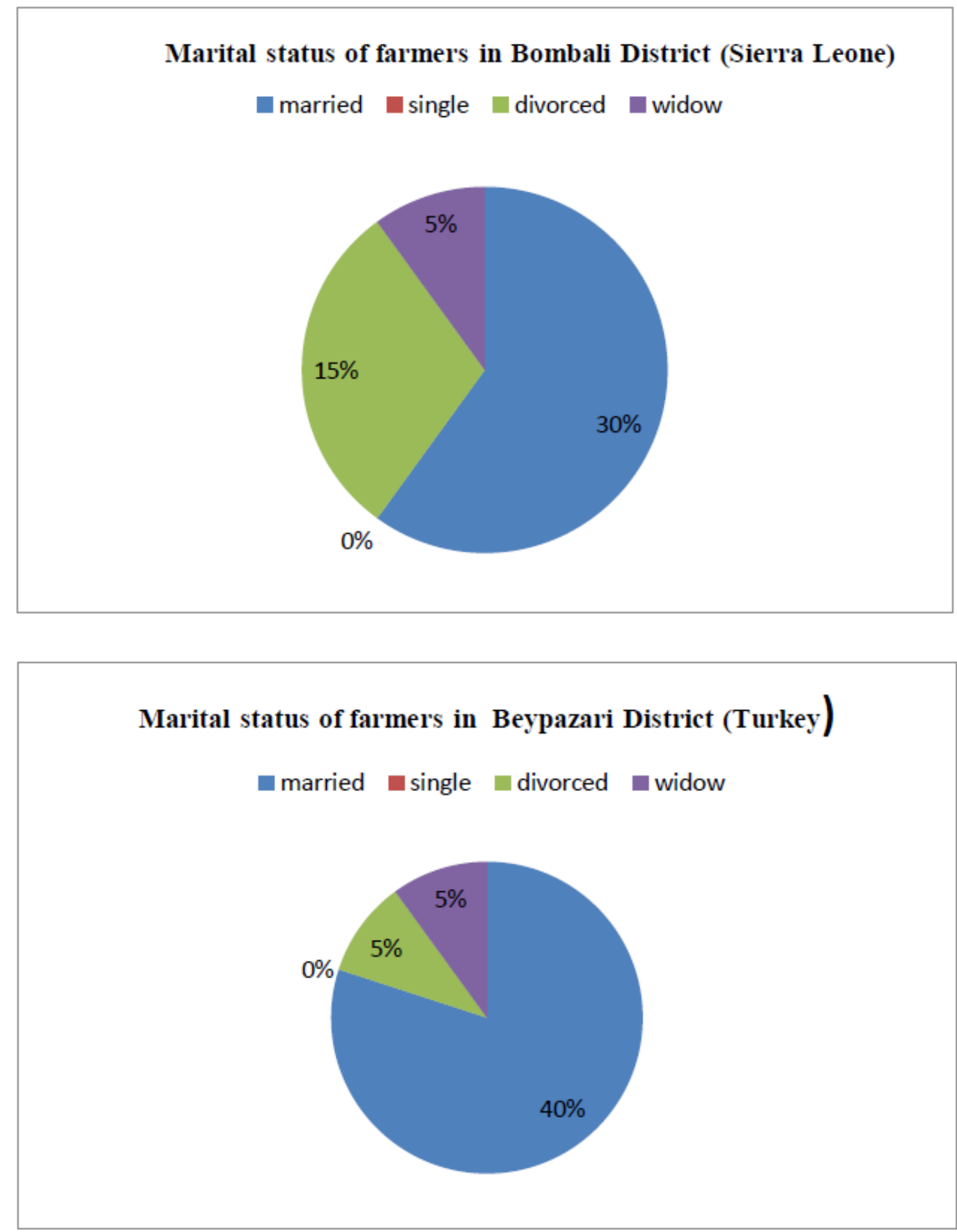

Figure 4.4 above shows the marital status of famers in Bombali District (Sierra Leone) and Beypazari District (Turkey) 


\section{Formal Education level}

Table 4.5 formal Education

\begin{tabular}{|l|l|l|l|l|l|l|}
\hline \multirow{2}{*}{ Country } & \multicolumn{3}{|l|}{ Formal Education } & \multirow{2}{*}{ Total } \\
\cline { 2 - 6 } & None & Primary & Secondary & Tertiary & Arabic & \\
\hline $\begin{array}{l}\text { Sierra } \\
\text { Leone }\end{array}$ & 20 & 15 & 5 & 2 & 8 & 50 \\
\hline Turkey & 2 & 5 & 23 & 20 & 0 & 50 \\
\hline $\begin{array}{l}\text { Sum } \\
\text { TOTAL }\end{array}$ & 22 & 20 & 28 & 22 & 8 & 100 \\
\hline
\end{tabular}

Figure 4.5 illustrates various level of education acquired by Vegetable farmers interviewed in Bombali District (Sierra Leone) and Beypazari District (Turkey). with respect to the level of education of vegetable farmers interviewed in Beypazari District (Turkey) out of the (50), (5\%) of the vegetable farmers interviewed attained primary school education, (23\%) acquired secondary school education, (20\%) pursue tertiary education while (2\%) acquired non formal education. However, no farmer interviewed in Beypazari District (Turkey) acquired Arabic education. Considering the (50) vegetable farmers interviewed in Bombali District (Sierra Leone), (15\%) attained primary school education, (5\%) completed secondary school, (2\%) attained tertiary education, (8\%) acquired Arabic education while (20\%) attained no formal education.

From the data, there are more secondary education level vegetable farmers in Beypazari District (Turkey) than Bombali District (Sierra Leone) and there is no Arabic education in Turkey (Beypazari District). 
level of eductation of farmers in beypazari district

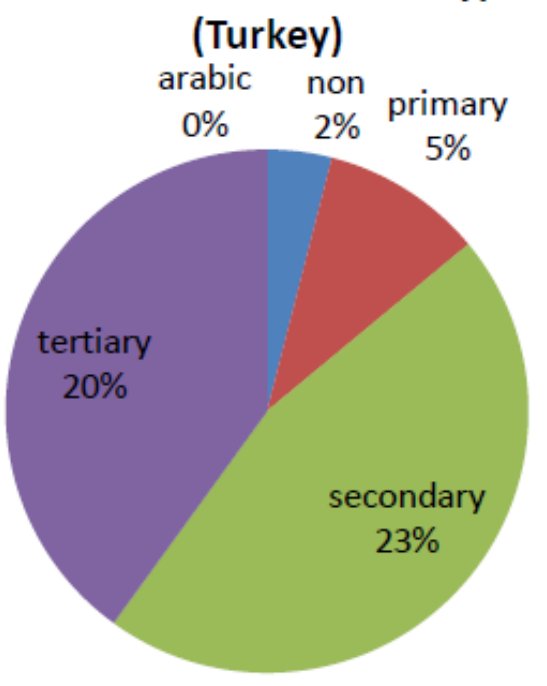

\section{level of eductation of farmers in bombali district(sierra leone)}

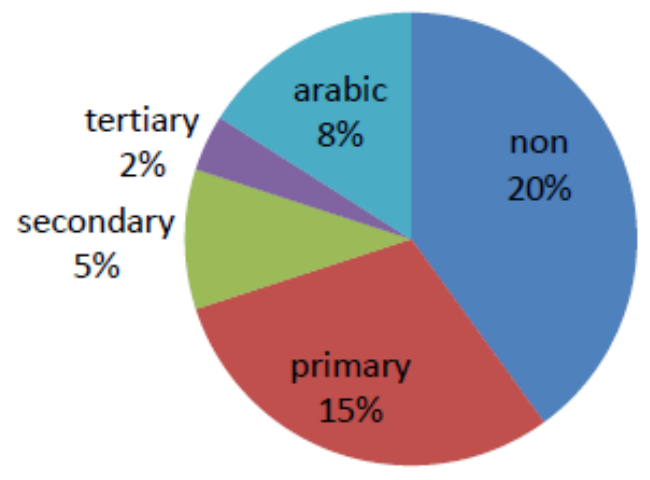

Figure 4.5 above illustrates various level of education acquired by farmers interviewed in Bombali District (Sierra Leone) and Beypazari District (Turkey) 


\section{Size of household}

Table 4.6 Size of house hold per farmer in Sierra Leone and Turkey

\begin{tabular}{|l|l|l|l|l|l|l|}
\hline \multirow{2}{*}{ Country } & \multicolumn{4}{|l}{ household members } & \multirow{2}{*}{ Total } \\
\cline { 2 - 6 } & Four & Five & Six & Seven & Nine & \\
\hline $\begin{array}{l}\text { Sierra } \\
\text { Leone }\end{array}$ & 10 & 15 & 11 & 10 & 4 & 50 \\
\hline Turkey & 0 & 12 & 14 & 13 & 11 & 50 \\
\hline $\begin{array}{l}\text { Sum } \\
\text { TOTAL }\end{array}$ & 10 & 27 & 25 & 23 & 15 & 100 \\
\hline
\end{tabular}

Figure 4.6 shows percentage of respondents interviewed both Bombali District (Sierra Leone) and Beypazari District (Turkey). Considering the (50) respondents interviewed in Sierra Leone (Bombali District), (10\%) of them have a family size of four (4), (15\%) have five (5) family members, $(11 \%)$ have a family of six (6), (10\%) have seven (7) members while (4\%) have a family of nine (9) members. Similarly for Turkey (Beypazari District), out of the 50 of respondents, (14\%) of them have a family size of six (6), (13\%) have seven (7) members, (11\%) have nine (9) family members while $(12 \%)$ have five (5) family members.

From the data, Turkey (Beypazari District) have more household member of six (6) than Sierra Leone (Bombali District). And there is no Household of four (4) in Turkey (Beypazari District) 
percentage of respondents in bombali district (sierra leone) basee on their familt size (Household)

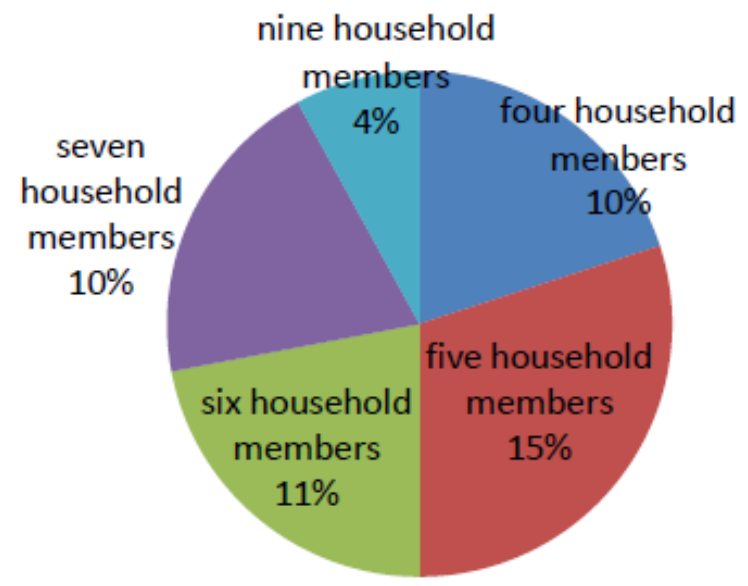

Percentage of respondent in beypazari district (Turkey) base on family size (household)

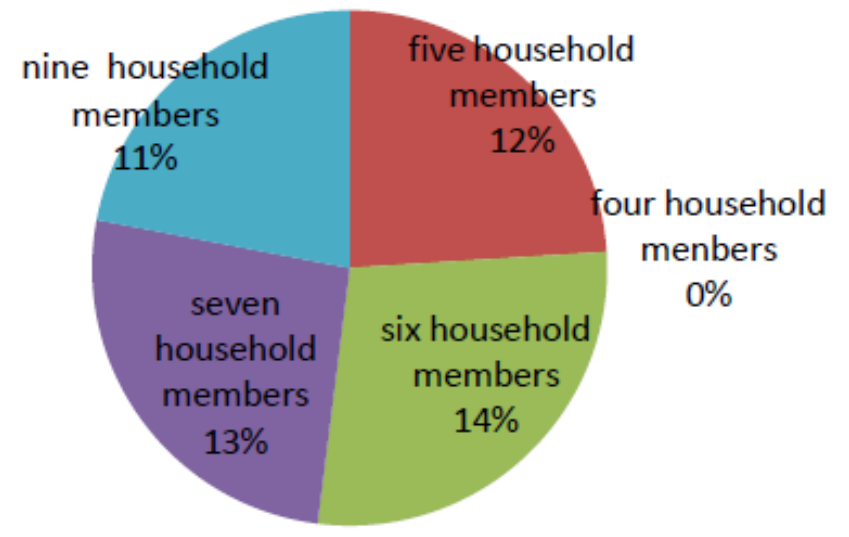

Figure 4.6 above shows percentage of respondents interviewed both Sierra Leone (Bombali District) and Turkey (Beypazari District). 
Estimated monthly income from all sources

Table 4.7 Monthly income per farmer in Sierra Leone and Turkey

\begin{tabular}{|c|c|c|c|c|}
\hline \multirow[t]{2}{*}{ Country } & \multicolumn{3}{|c|}{ Monthly income (TL) } & \multirow{2}{*}{ Total } \\
\hline & $0-5,000$ & $5,0001-10,000$ & $10,000-20,000$ & \\
\hline \multirow[t]{3}{*}{ Turkey } & 37 & 12 & 1 & 50 \\
\hline & \multicolumn{3}{|c|}{ Monthly income (LE) } & \multirow[t]{2}{*}{ Total } \\
\hline & $0-200,000$ & $\begin{array}{ll}300,000 & - \\
500,000\end{array}$ & 600,000 upwards & \\
\hline $\begin{array}{l}\text { Sierra } \\
\text { Leone }\end{array}$ & 21 & 25 & 4 & 50 \\
\hline Sum total & 58 & 37 & 5 & 100 \\
\hline
\end{tabular}

Figure 4.7 illustrates monthly income generated by farmers in Bombali District (Sierra Leone) and Beypazari District (Turkey). With respect to the (50) vegetable farmers interviewed in Sierra Leone (Bombali District), (21\%) generated a total of Le 0- 200,000 thousand Leones monthly, (25\%) earn Le 300,000-500,000 while (4\%) received Le 600,000 thousand Leones upwards. Likewise for Turkey (Beypazari District), (37\%) of the farmers interviewed earned an estimated amount of $0-5,000$ tl per month, (12\%) received 5,000-10,000tl while (1\%) earned 10,00020,000tl monthly.

From the data, considering the exchange rate Vegetable farmers in Turkey (Beypazari District) earned more income compare to vegetable farmers in Sierra Leone (Bombali District). 
International Journal of Agriculture and Environmental Research
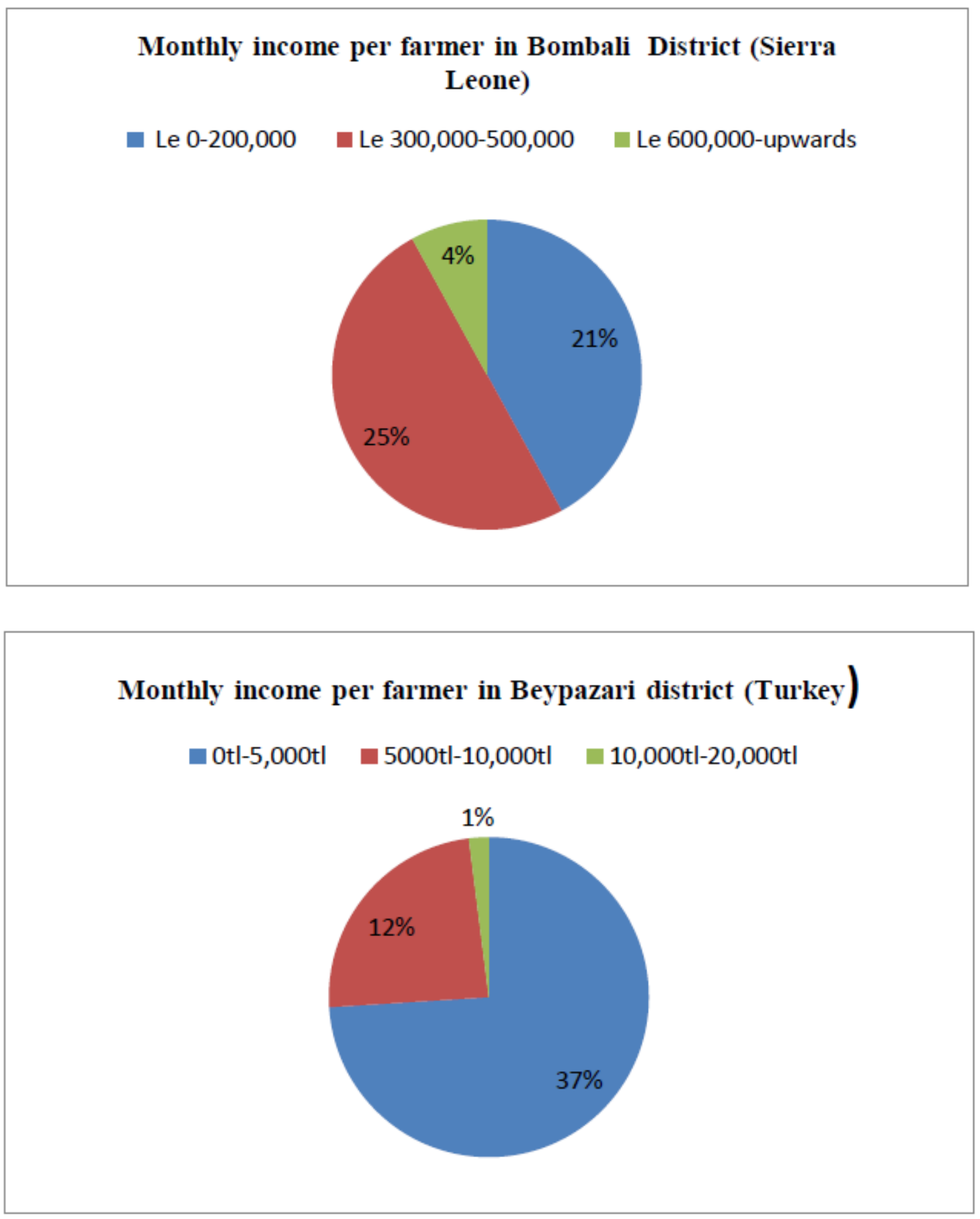

Figure 4.7 above illustrates monthly income generated by farmers in Bombali District (Sierra Leone) and Beypazari District (Turkey) 
International Journal of Agriculture and Environmental Research

ISSN: 2455-6939

Volume: 07, Issue: 04 "July-August 2021"

The new situation caused by climate change in pest controls activities

Years managing crops

Table 4.8 Duration of managing crops by farmers in Sierra Leone and Turkey

\begin{tabular}{|l|l|l|l|l|l|l|}
\hline \multirow{2}{*}{ Country } & \multicolumn{5}{|l|}{ Duration of managing crops } & \multirow{2}{*}{ Total } \\
\cline { 2 - 6 } & five years & six years & seven years & eight years & ten years & \\
\hline $\begin{array}{l}\text { Sierra } \\
\text { Leone }\end{array}$ & 10 & 15 & 12 & 9 & 4 & 50 \\
\hline Turkey & 15 & 7 & 8 & 10 & 10 & 50 \\
\hline $\begin{array}{l}\text { Sum } \\
\text { TOTAL }\end{array}$ & 25 & 22 & 20 & 19 & 14 & 100 \\
\hline
\end{tabular}

Figure 4.8 shows the percentage of farmers interviewed both the two countries base on the duration of managing crops. With regards to the duration of crop management by vegetable farmers, out of (50) vegetable farmers in Bombali District (Sierra Leone), (10\%) of them have consecutively managed crops almost five (5) years, (15\%) have managed for a period of six (6) years, $(12 \%)$ for a period of seven (7), $9 \%$ have managed for a period of eight (8) years while $4 \%$ have engaged in crop management for a period of ten (10) years. similarly for Turkey (Beypazari District), out of the (50) vegetable farmers interviewed, (15\%) of them have managed crops for a period of five (5) years, (7\%) for six (6) years, $(8 \%)$ for seven (7) years, $(10 \%)$ for eight (8) years and $(10 \%)$ for ten (10) years in crop management respectively.

From the data, Turkey (Beypazari District) vegetable farmers have spent up to ten (10) on vegetables farming than Sierra Leone (Bombali District) 
International Journal of Agriculture and Environmental Research

ISSN: 2455-6939

Volume: 07, Issue: 04 "July-August 2021"

Duration of managing crops by farmers in bombali District (Sierra Leone)

five years $\square$ six years $\square$ seven years $\square$ eight years $\square$ ten years

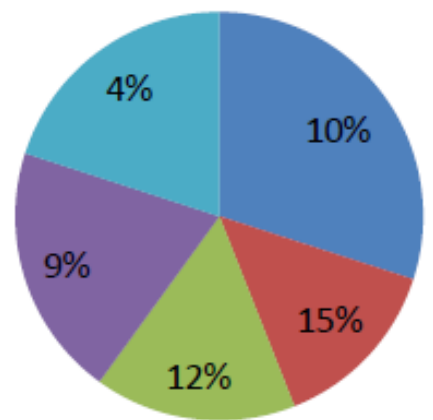

Duration of managing crops by farmers in Beypazari District (Turkey)

$\square$ five years $\square$ six years $\square$ seven years $\square$ eight years $\square$ ten years

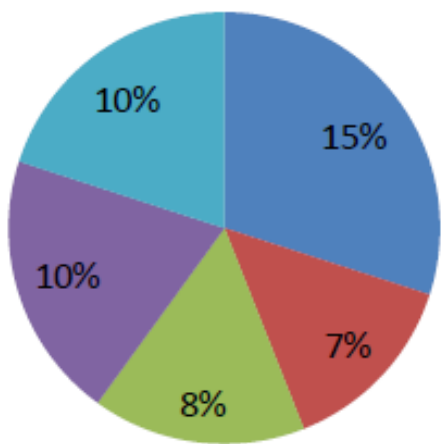

Figure 4.8 above shows the percentage of farmers interviewed both the two countries base on the duration of managing crops 
International Journal of Agriculture and Environmental Research

ISSN: 2455-6939

Volume: 07, Issue: 04 "July-August 2021"

Table 4.9 Hectares of land prepared for crop production by farmers in Sierra Leone and Turkey

\begin{tabular}{|l|l|l|l|l|l|l|}
\hline Country & \multicolumn{4}{|l}{ Hectares used for crop production } & Total \\
\cline { 2 - 7 } & $\begin{array}{l}\text { three } \\
\text { Hectares }\end{array}$ & $\begin{array}{l}\text { five } \\
\text { Hectares }\end{array}$ & $\begin{array}{l}\text { seven } \\
\text { Hectares }\end{array}$ & $\begin{array}{l}\text { eight } \\
\text { Hectares }\end{array}$ & $\begin{array}{l}\text { ten } \\
\text { Hectares }\end{array}$ & \\
\hline $\begin{array}{l}\text { Sierra } \\
\text { Leone }\end{array}$ & 10 & 12 & 13 & 8 & 7 & 50 \\
\hline Turkey & 5 & 10 & 15 & 12 & 8 & 50 \\
\hline $\begin{array}{l}\text { Sum } \\
\text { TOTAL }\end{array}$ & 15 & 22 & 28 & 20 & 15 & 100 \\
\hline
\end{tabular}

Figure 4.9 illustrates percentage of farmers cultivated various farm size (hectares) for crop production in Bombali District (Sierra Leone) and Beypazari District (Turkey). considering the (50) vegetable famers interviewed in Sierra Leone (Bombali District), (10\%) cultivated three (3) hectares, (12\%) cultivated five (5) hectares, (13\%) cultivated seven (7) hectares, (8\%) cultivated eight (8) hectares while seven (7\%) cultivated ten (10) hectares for their crop production. Similarly for Turkey (Beypazari District), out of the (50) respondents interviewed, (5\%) of farmed on three (3) hectares of land, (10\%) cultivated five (5) hectares, $(15 \%)$ farmed on seven (7) hectares, (12\%) cultivated eight (8) hectares while (8\%) of them cultivated almost ten (10) hectares of land for crop production.

From the data, Turkey (Beypazari District) use more hectares of land than Sierra Leone (Bombali District). 
International Journal of Agriculture and Environmental Research

ISSN: 2455-6939

Volume: 07, Issue: 04 "July-August 2021"
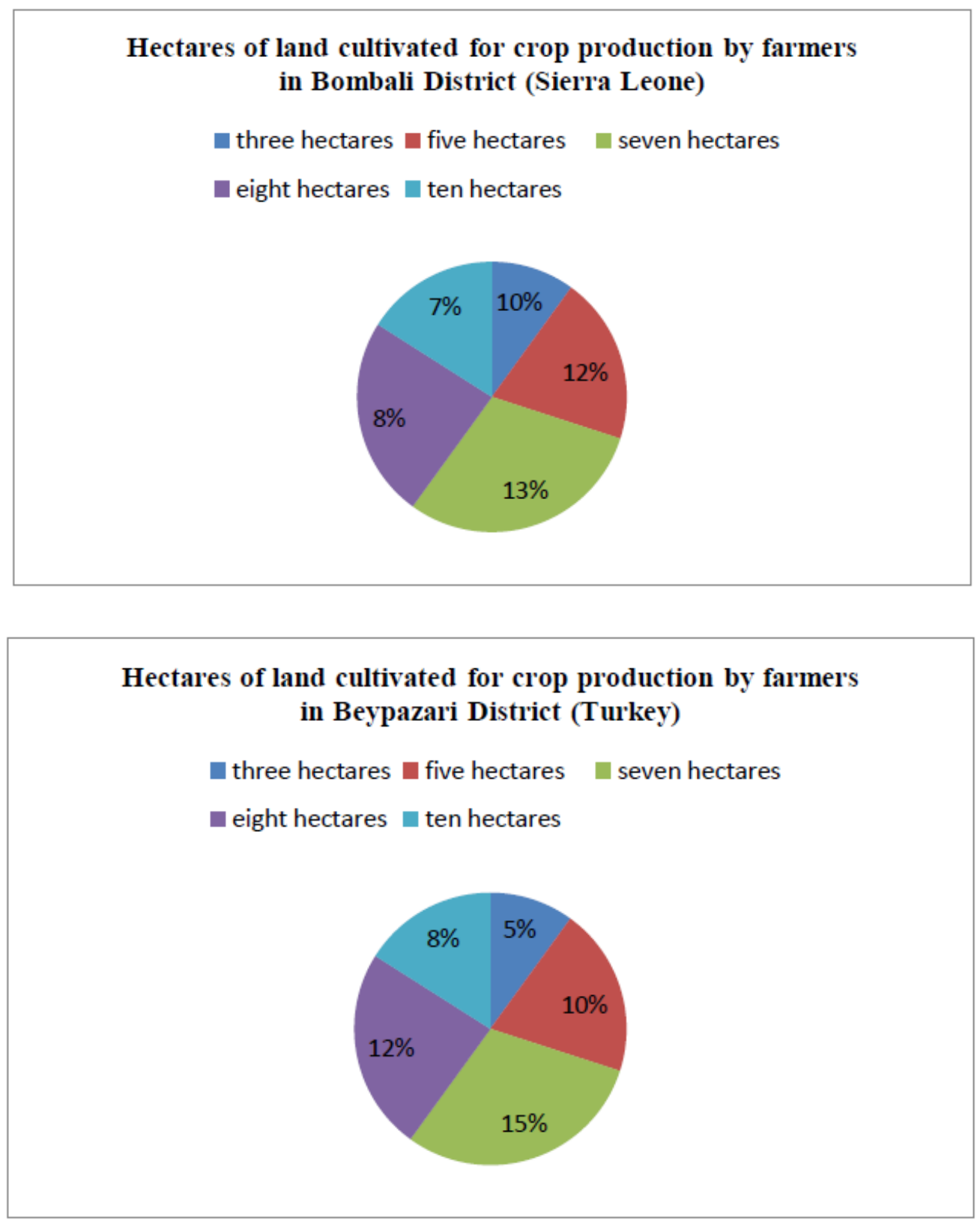

Figure 4.9 above illustrates percentage of farmers cultivated various farm size (hectares) for crop production in Bombali District (Sierra Leone) and Beypazari District (Turkey) 
International Journal of Agriculture and Environmental Research

ISSN: 2455-6939

Volume: 07, Issue: 04 "July-August 2021"

\section{The main vegetable crops}

Table 4.10 Type of crop cultivated by farmers in Sierra Leone and Turkey

\begin{tabular}{|c|c|c|c|c|c|c|c|c|c|c|c|c|c|}
\hline 苞 & 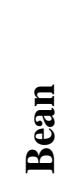 & 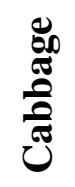 & $\overrightarrow{\tilde{n}}$ & 萢 & 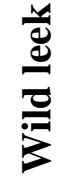 & 。ేٍ & 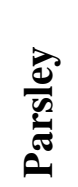 & $\stackrel{\Phi}{ \pm}$ & : & 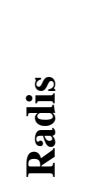 & 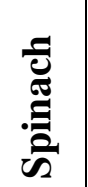 & & $\stackrel{\bar{\sigma}}{\frac{\pi}{\theta}}$ \\
\hline $\begin{array}{l}\text { Sierra } \\
\text { Leone }\end{array}$ & 5 & 7 & 6 & 3 & 2 & 4 & 5 & 3 & 6 & 2 & 3 & 4 & 50 \\
\hline Turkey & 4 & 6 & 7 & 4 & 4 & 5 & 3 & 4 & 4 & 3 & 4 & 2 & 50 \\
\hline $\begin{array}{l}\text { Sum } \\
\text { TOTAL }\end{array}$ & 9 & 13 & 13 & 7 & 6 & 9 & 8 & 7 & 10 & 5 & 7 & 6 & 100 \\
\hline
\end{tabular}

Figure 4.10 illustrates the type of crops cultivated by farmers in Sierra Leone and Turkey. This crops are beans, cabbage, carrot, lettuce, wild leek onion, parsley, tomato, pepper, pea, radish and spinach both farmers within the two countries respectively. In Sierra Leone (Bomabli District), out of the fifty vegetable farmers interviewed five (5) of them mentioned that they grow beans, seven (7) cabbage, six (6) carrot, three (3) of them mentioned that they grow lettuce, two (2) mentioned that they grow wild leek, four (4) mentioned they grow onion, five (5) mentioned that they grow parsley, three (3) of the vegetable farmers mentioned that they grow pea, six (6) of them mentioned that they grow pepper, two (2) mentioned that they grow radish, three (3) vegetable farmers mentioned that they grow spinach and four (4) of the vegetable farmers mentioned that they grow tomato.

Likewise for Turkey (Beypazari District), out of the fifty (50) vegetable farmers interviewed four (4) mentioned that they grow beans, six (6) mentioned that they grow cabbage, seven (7) mentioned that they grow carrot, four (4) of the vegetable farmers mentioned that they grow lettuce, four (4) of the vegetable farmers mentioned that they grow wild leek, five (5) vegetable farmers mentioned that they grow onion, three (3) of the vegetable farmers grow parsley, four (4) of the vegetable farmers mentioned that they grow pee, four (4) of the vegetable farmers mentioned that they pepper, three (3) mentioned that they grow radish, four (4) vegetable farmers mentioned that they grow spinach and only two (2) mentioned that they grow tomato respectively.

From the data, Sierra Leone (Bombali District) farmers grow more cabbage, pepper and tomato, than Turkey (Beypazari District). 


\section{Type of crops cultivated by farmers in Bambali}

District (Sierra Leone)

$\square$ bean $\square$ cabbage $\square$ carrot $\square$ lettuce $\square$ wild leek $\square$ onion
$\square$ parsley $\square$ pea $\square$ pepper $\square$ raddish $\square$ spinach $\square$ tomato

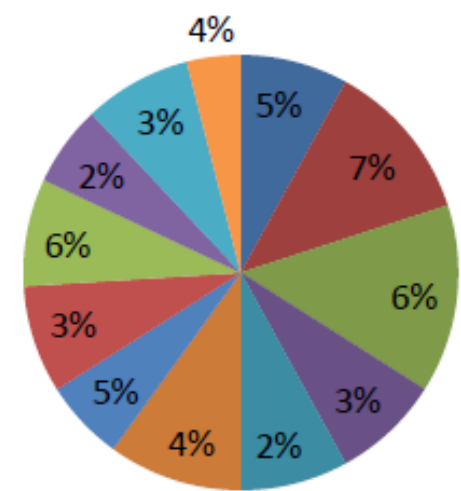

Type of crops cultivated by farmers in Beypazari (Turkey)

$\square$ bean $\square$ cabbage $\square$ carrot $\quad$ lettuce $\square$ wild leek $\square$ onion
$\square$ parsley $\square$ pea $\quad$ pepper $\quad$ raddish $\square$ spinach $\quad$ tomato

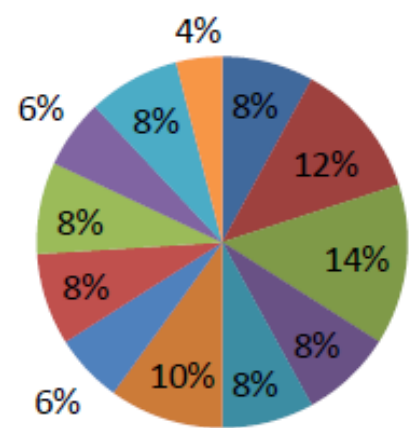

Diagram 4.10 above shows the percentage of farmers engaged in the production of different type of crops in Bombali District (Sierra Leone) and Beypazari District (Turkey) 


\section{Identify the factors affecting farmer decisions making process on pest control activities}

However with further discussion with the vegetable farmers on pest control activities within the two countries (Sierra Leone and Turkey), most of them use the following strategy in pest control decisions which is communicating and coordinating management practices between the producer and the agricultural consultant on adopt cultural practices as a first line of defenses such as plan and implantation of new verity selection and accurately identify pest and species composition and quantify population and also develop a scouting technique,control plans and monitoring the ecology of the insect pest it intercropping relationships in the agricultural field. Notwithstanding, some of the major factors affecting their decision making is the Field Topography and Crop and Variety Selection.

\section{Receiving any training on pest management for your vegetable farm}

Table 4.11 vegetable farmers that received training on pest management

\begin{tabular}{|l|l|l|l|}
\hline \multirow{2}{*}{ Country } & \multicolumn{2}{|l|}{ Training received on pest management } & \multirow{2}{*}{ Total } \\
\cline { 2 - 4 } & Yes & No & \\
\hline Sierra Leone & 15 & 35 & 50 \\
\hline Turkey & 45 & 5 & 50 \\
\hline Sum TOTAL & 60 & 40 & 100 \\
\hline
\end{tabular}

Figure 4.11 illustrates percentage of farmers who received pest management training and those who do not received any training on pest management in Bombali District (Sierra Leone) and Beypazari District (Turkey). Out of the total farmers, (50) that were interviewed in Sierra Leone (Bombali District), (15\%) received training on pest management while (35\%) are not. Similarly for Turkey (Beypazari District), (45\%) of the interviewed farmers received training on pest management while $(5 \%)$ received no training.

From the data, there are more vegetable farmers in Turkey (Beypazari District) that received training on pest management compare to Sierra Leone (Bombali district). 

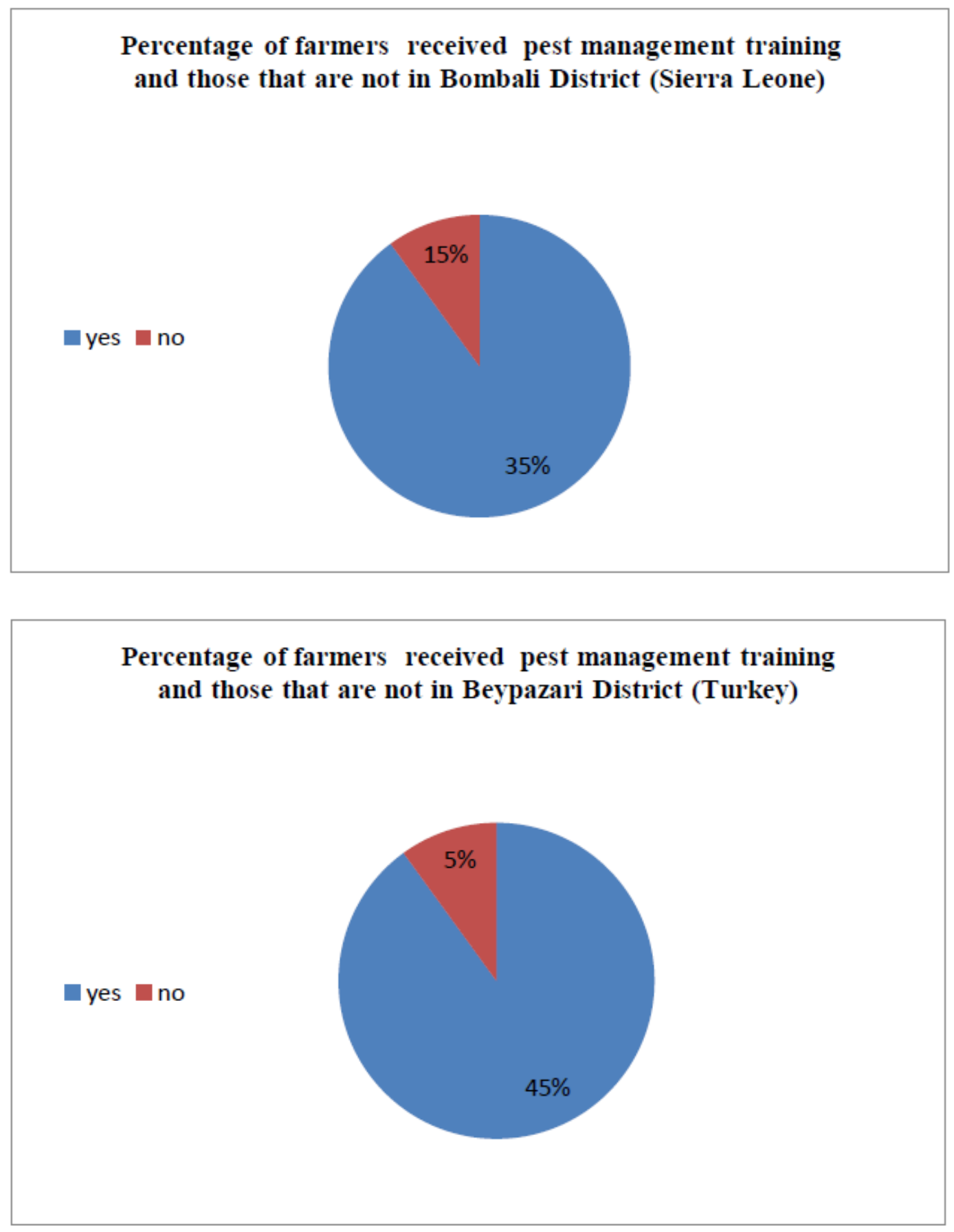

Figure 4.11 above illustrates percentage of farmers who received pest management training and those who do not received any training on pest management in (Sierra Leone) and (Turkey) 


\section{If yes which of the following}

Table 4.12 Methods of pest management

\begin{tabular}{|l|l|l|l|l|l|}
\hline Country & Biological & Chemical & Mechanical & Trapped & Total \\
\hline $\begin{array}{l}\text { Sierra } \\
\text { Leone }\end{array}$ & 10 & 30 & 5 & 5 & 50 \\
\hline Turkey & 15 & 25 & 7 & 3 & 50 \\
\hline $\begin{array}{l}\text { Sum } \\
\text { TOTAL }\end{array}$ & 25 & 55 & 12 & 8 & 100 \\
\hline
\end{tabular}

Figure 4.12 illustrate various methods of pest management, the vegetable farmers interviewed in Sierra Leone (Bombali District) and Turkey (Beypazari District) used biological, chemical, mechanical, and trapped methods of pest control. In addition, out of the fifty (50) vegetable farmers interviewed ten (10) of them used Biological methods of pest management, thirty (30) of them used chemical methods of pest management, five (5) used mechanical methods and five (5) of them used trapped method. Similarly for Turkey (Beypazari District) fifteen (15) of the vegetable farmers interviewed used Biological method, twenty five (25) adopt the chemical method, seven (7) practiced the mechanical method while three (3) of the farmers chose the trapped method of pest control.

From the data, Turkey (Beypazari District) vegetable use more of chemical in pest management compare to Sierra Leone (Bombali District) 
International Journal of Agriculture and Environmental Research
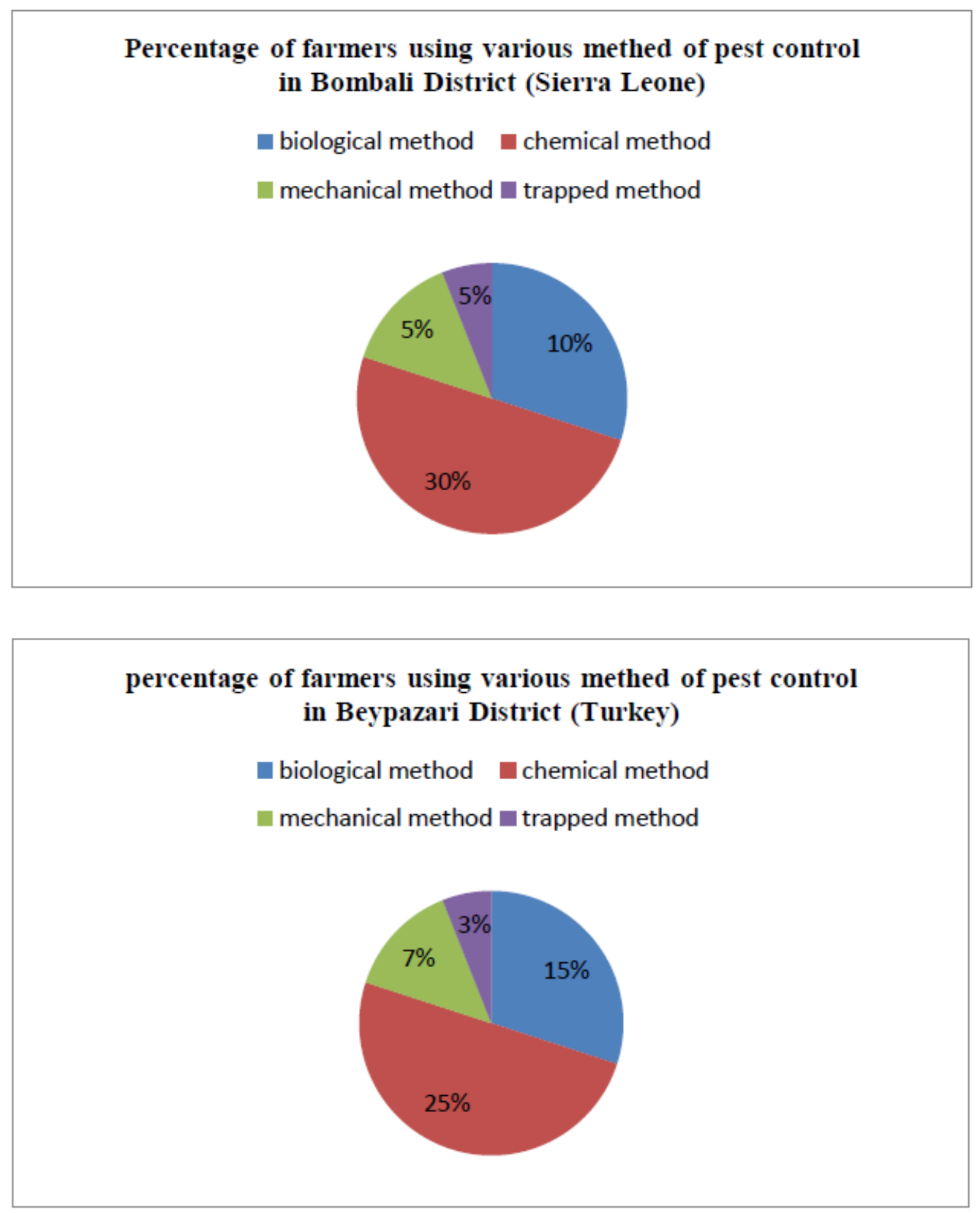

Figure 4.12 above shows the percentage of farmers using various method of pest control in Bombali District (Sierra Leone) and Beypazari District (Turkey) 


\section{Practice crop rotation}

Table 4.13 Practice crop rotation

\begin{tabular}{|l|l|l|l|}
\hline \multirow{2}{*}{ Country } & \multicolumn{2}{|c|}{ Practice crop rotation } & \multirow{2}{*}{ Yes } \\
\cline { 2 - 3 } & No & Total \\
\hline $\begin{array}{l}\text { Sierra } \\
\text { Leone }\end{array}$ & 18 & 32 & 50 \\
\hline Turkey & 35 & 15 & 50 \\
\hline $\begin{array}{l}\text { Sum } \\
\text { TOTAL }\end{array}$ & 53 & 47 & 100 \\
\hline
\end{tabular}

Figure 4.13 illustrates percentage of farmer practiced crop rotation and those not practicing such method in Bombali District (Sierra Leone) and Beypazari District (Turkey). in Sierra Leone (Bombali District), out of the (50) vegetable farmers interviewed (18\%) of them practice the system while (32\%) are not. Likewise Turkey (Beypazari District), (35\%) of the farmers practiced crop rotation while $(15 \%)$ were not.

From the data, vegetable farmers in Turkey (Beypazari District) practices crop rotation than vegetable farmers in Sierra Leone (Bombali District). 
International Journal of Agriculture and Environmental Research
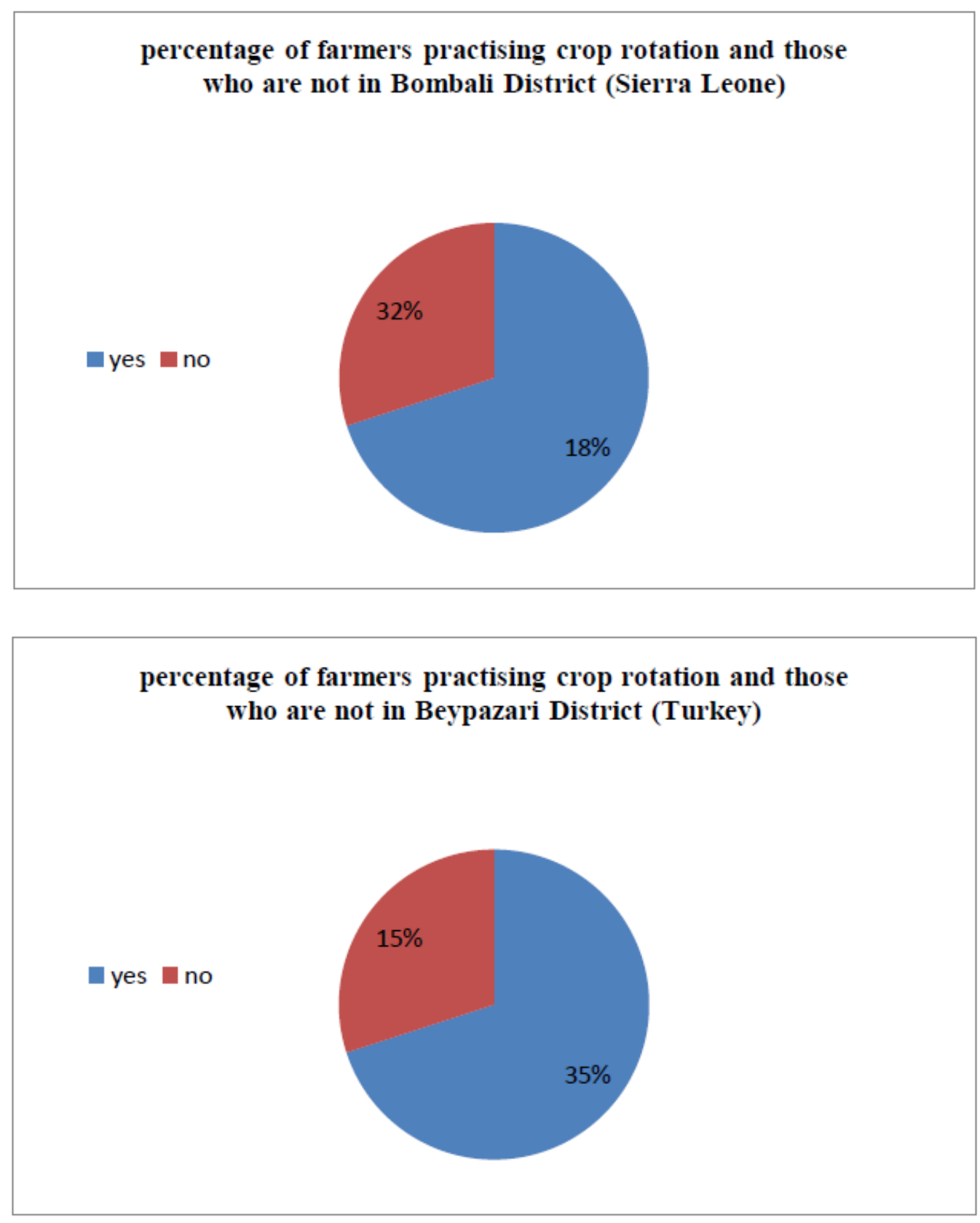

Figure 4.13 above represent illustrates percentage of farmer practiced crop rotation and those not practicing such method in Bombali District (Sierra Leone) and Beypazari District (Turkey) 
Answer for question number 14 is yes, which crops?

Table 4.14 Practice crop rotation and the type crops

\begin{tabular}{|l|l|l|l|l|l|}
\hline Country & rice & ground nut & maize & cassava & Total \\
\hline $\begin{array}{l}\text { Sierra } \\
\text { Leone }\end{array}$ & 20 & 15 & 10 & 5 & 50 \\
\hline Turkey & 15 & 15 & 10 & 10 & 50 \\
\hline $\begin{array}{l}\text { Sum } \\
\text { TOTAL }\end{array}$ & 35 & 30 & 20 & 15 & 100 \\
\hline
\end{tabular}

Figure 4.14 shows Percentage of respondent's base on the use of different crops for crop rotation in Bombali District (Sierra Leone) and Beypazari District (Turkey). with respect to the (50) targeted vegetable farmers in Sierra Leone (Bombali District) regarding crop use for their crop rotation practices, $(20 \%)$ of them normally use rice for the rotational practice, $(15 \%)$ chose groundnut, $(10 \%)$ prefer maize while $(5 \%)$ selected cassava as a choice for such practices. Similarly, out of the (50) of vegetable farmers interviewed in Beypazari District (Turkey), (15\%) of the farmers chose rice for rotational practice, (15\%) selected groundnut, (10\%) prefer maize while (10\%) used cassava for the above purpose.

From the data, vegetable farmers in Bombali District (Sierra Leone) use rice for crop rotation compare to Turkey (Beypazari District). 
Percentage of farmers using different crops with the practise of rotational method in Bombali District (Sierra

\section{Leone)}

Rice $\quad$ Rround nut $\square$ Maize $\quad$ Cassava

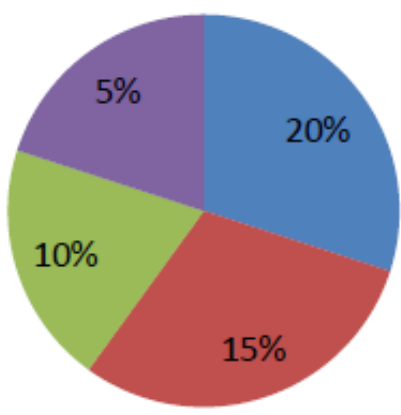

Percentage of farmers using different crops with the practise of rotational method in Beypazari District

(Turkey)

Rice $\quad$ Rround nut Maize $\quad$ Cassava

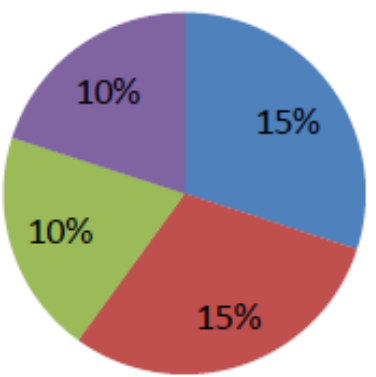

Figure 4.15 above represents Percentage of respondents' base on the use of different crops for crop rotation in Bombali District (Sierra Leone) and Beypazari District (Turkey) 


\section{The new climate conditions}

Table 4.15 New weather affecting pest control at current locations

\begin{tabular}{|l|l|l|l|l|l|l|}
\hline Country & $\begin{array}{l}\text { Unpredictable } \\
\text { temperature }\end{array}$ & $\begin{array}{l}\text { Low } \\
\text { growing } \\
\text { season }\end{array}$ & $\begin{array}{l}\text { High } \\
\text { temperature }\end{array}$ & $\begin{array}{l}\text { High } \\
\text { moisture }\end{array}$ & $\begin{array}{l}\text { Strong } \\
\text { rainfall }\end{array}$ & Total \\
\hline $\begin{array}{l}\text { Sierra } \\
\text { Leone }\end{array}$ & 10 & 20 & 10 & 6 & 4 & 50 \\
\hline Turkey & 15 & 10 & 10 & 7 & 8 & 50 \\
\hline $\begin{array}{l}\text { Sum } \\
\text { TOTAL }\end{array}$ & 25 & 30 & 20 & 13 & 12 & 100 \\
\hline
\end{tabular}

Figure 4.15 shows the new weather affecting pest control at the current locations of the farmers. Of the farmers interviewed both in Sierra Leone (Bombali District) and Turkey (Beypazari District) experienced unpredictable temperature, low growing season, high temperature, high moisture content, and strong rain fall in their respective locations. However, out of the fifty (50) vegetable farmers interviewed in Sierra Leone (Bombali District), ten (10) of the vegetable farmers interviewed lamented the unpredictable temperature, twenty (20) mentioned the low growing season, ten (10) elaborated on the high temperature, six (6) mentioned high moisture content while four (4) of them emphasis on the strong rainfall. Similarly for Turkey (Beypazari District), fifteen (15) of the vegetable farmers interviewed emphasize the unpredictable temperature, ten (10) lamented on the low growing season, ten (10) of them elaborated on the high temperature, seven (7) mentioned high moisture while eight (8) of the stressed rain fall.

From the data, Beypazari District (Turkey) experienced unpredictable temperature compared to Bombali District (Sierra Leone). And also in Bombali District (Sierra Leone) experienced low growing season compared to Beypazari District (Turkey). 

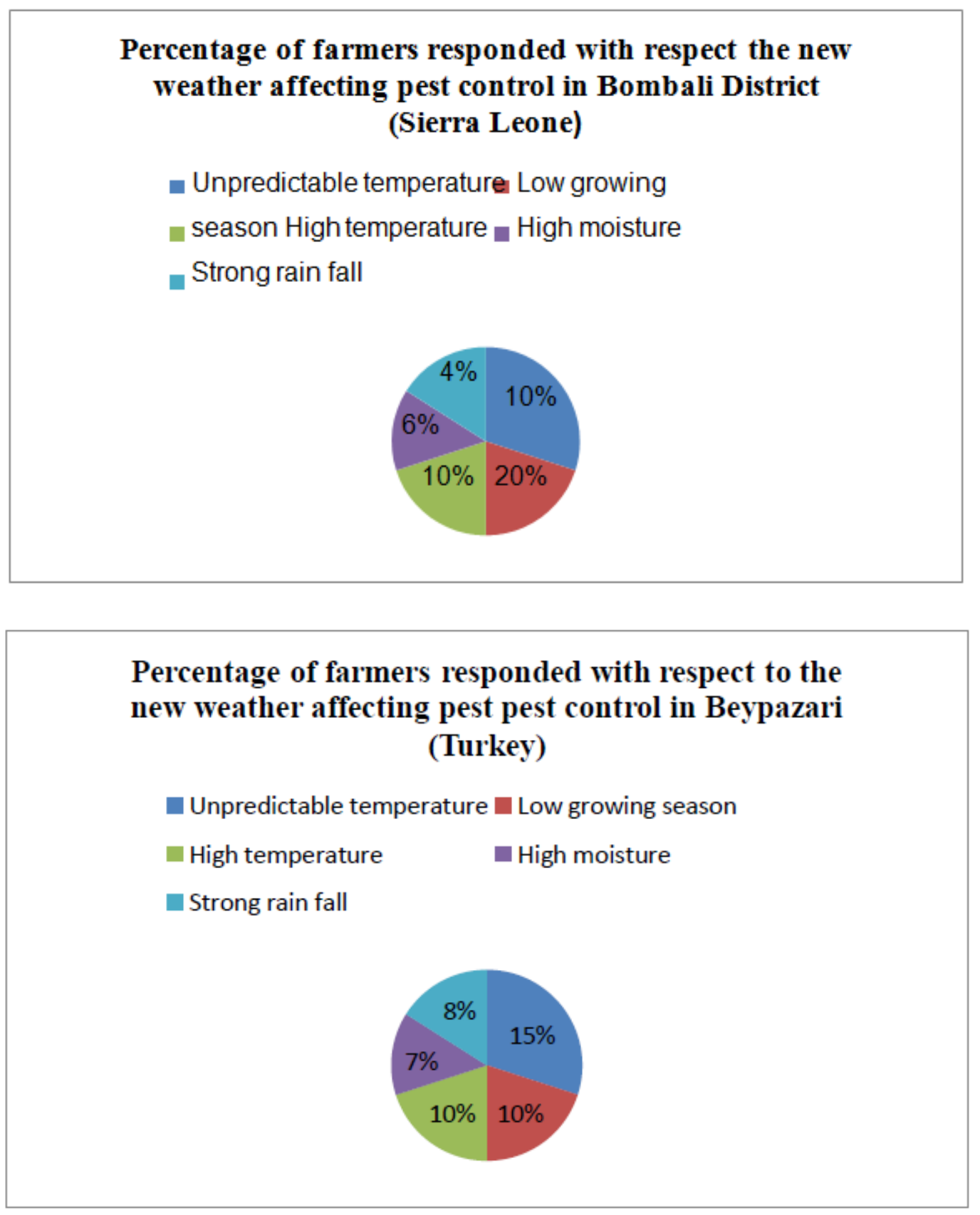

Figure 4.15 above represent Percentage of farmers responded regarding the new weather affecting pest control in Bombali District (Sierra Leone) and Beypazari District (Turkey) 


\section{Practice inter-cropping}

Table 4.16 Practice of inter- cropping

\begin{tabular}{|l|l|l|l|}
\hline \multirow{2}{*}{ Country } & \multicolumn{2}{|l|}{ Farmers practicing intercropping } & \multirow{2}{*}{ Total } \\
\cline { 2 - 3 } & Yes & No & \\
\hline Sierra Leone & 35 & 15 & 50 \\
\hline Turkey & 40 & 10 & 50 \\
\hline Sum TOTAL & 75 & 25 & 100 \\
\hline
\end{tabular}

Figure 4.16 Percentage of farmers practicing intercropping and those not practicing such method in Bombali District (Sierra Leone) and Beypazari District (Turkey). with regards to the target population of farmers (50) interviewed in Bombali District (Sierra Leone), (35\%) of them practiced intercropping while (15\%) were not. Likewise Turkey (Beypazari District), an estimated percentage of (40\%) farmers practiced intercropping while (10\%) were not.

From the data, Turkey (Beypazari District) vegetable farmers practice intercropping than vegetable farmers in Sierra Leone (Bombali District)

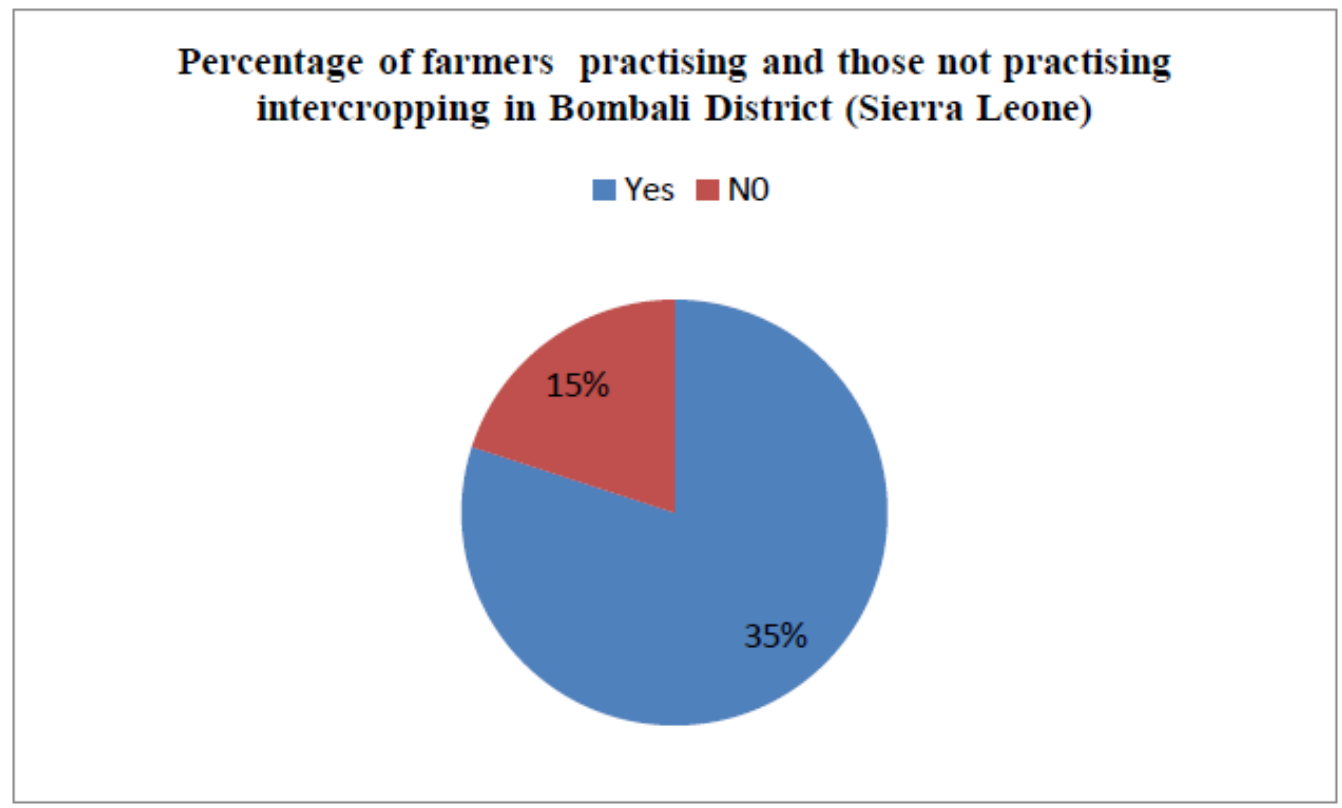




\section{Percentage of farmers practising and those not practising} intercropping in Beypazari District (Turkey)

$$
\square \text { Yes } \square \text { NO }
$$

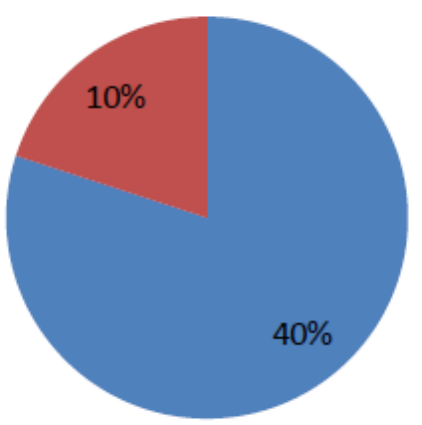

Figure 4.16 above represent Percentage of farmers practicing intercropping and those not practicing such method in Bombali District (Sierra Leone) and Beypazari District (Turkey)

Answer for question number 17 is yes, which crops

Table 4.17 Crops use for intercropping by farmers in Sierra Leone and Turkey

\begin{tabular}{|c|c|c|c|c|c|c|}
\hline \multirow[t]{2}{*}{ Country } & \multicolumn{5}{|c|}{ Crops use for intercropping } & \multirow[t]{2}{*}{ TOTAL } \\
\hline & 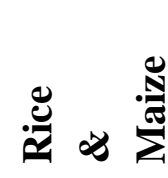 & 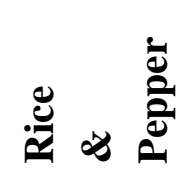 & 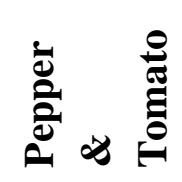 & 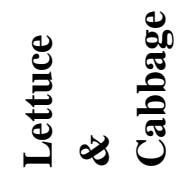 & 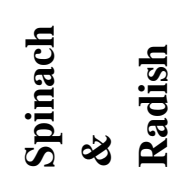 & \\
\hline $\begin{array}{l}\text { Sierra } \\
\text { Leone }\end{array}$ & 20 & 10 & 6 & 7 & 7 & 50 \\
\hline Turkey & 15 & 15 & 10 & 6 & 4 & 50 \\
\hline $\begin{array}{l}\text { Sum } \\
\text { TOTAL }\end{array}$ & 35 & 25 & 16 & 13 & 11 & 100 \\
\hline
\end{tabular}

Considering crop use for intercropping, of the one hundred (100) vegetable farmers interviewed in Sierra Leone (Bombali District) and Turkey (Beypazari District) they intercropped rice and maize, rice and pepper, pepper and tomato, lettuce and cabbage, Spinach and radish respectively. 
In Sierra Leone (Bombali District), out of the fifty (50) vegetable farmers interviewed, twenty (20) of the farmers intercropped rice and maize together, ten (10) intercropped rice and pepper, six (6) intercropped pepper and tomato, and seven (7) intercropped lettuce and cabbage while seven (7) intercropped spinach and radish together. Similarly for Turkey (Beypazari District), out of fifty (50) vegetable farmers, fifteen (15) of the vegetable farmers interviewed intercropped rice and maize altogether, fifteen (15) of them intercropped rice and pepper, ten (10) of the farmers intercropped pepper and tomato, six (6) of them intercropped lettuce and cabbage while four (4) of them intercropped spinach and radish altogether.

Use any pesticides in your vegetable garden, If yes, which of the following do you use

Table 4.18 illustrates the various pesticides used

\begin{tabular}{|l|l|l|l|l|}
\hline Country & $\begin{array}{l}\text { insecti } \\
\text { cides }\end{array}$ & herbicides & fungicides & Total \\
\hline $\begin{array}{l}\text { Sierra } \\
\text { Leone }\end{array}$ & 20 & 20 & 10 & 50 \\
\hline Turkey & 15 & 15 & 20 & 50 \\
\hline $\begin{array}{l}\text { Sum } \\
\text { TOTAL }\end{array}$ & 35 & 35 & 30 & 100 \\
\hline
\end{tabular}

Figure 4.17 Percentage of farmers using various pesticides on their crop production in Bombali district (Sierra Leone) and Beypazari District (Turkey). Considering the percentage of targeted farmers, out of the (50) in Bombali District (Sierra Leone), (20\%) of the farmers applied insecticides for pest control, (20\%) used herbicides while (10\%) applied fungicides. With regards to farmers interviewed in Beypazari District (Turkey), (15\%) of the farmers interviewed used insecticides, (15\%) applied herbicides while (20\%) applied fungicides.

From the data, vegetable farmers in Bombali District (Sierra Leone) used more insecticides than Beypazari District (Turkey), while Beypazari District (Turkey) used more fungicide than Sierra Leone (Bombali District). 
Percentage of farmers using various pesticides on crop production in Bombali District (Sierra Leone)

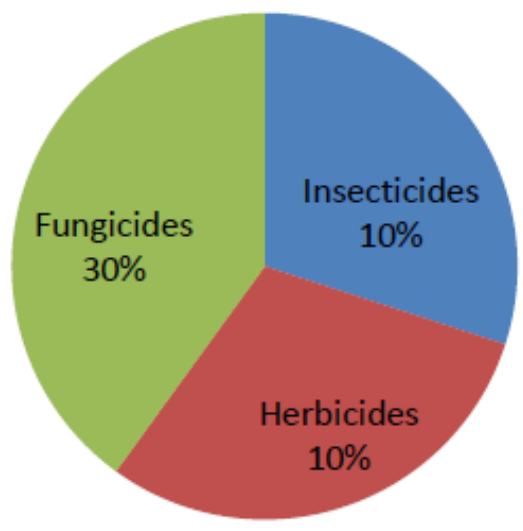

Percentage of farmers using various pesticides on the crop production in Beypazari District (Turkey)

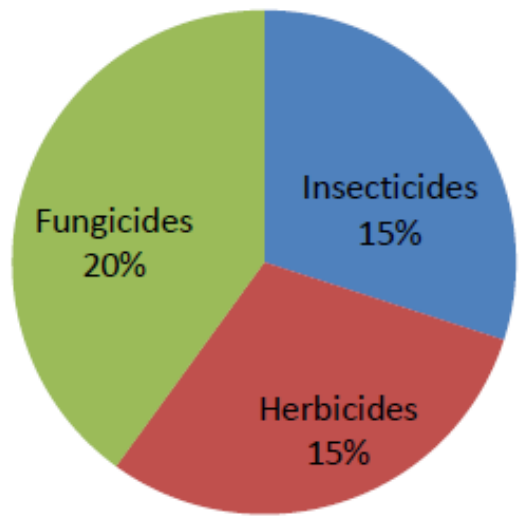

Figure 4.17 above represent Percentage of farmers using various pesticides on their crop production in Bombali District (Sierra Leone) and Beypazari District (Turkey) 


\section{Frequency of using Pesticides}

Table 4.19 the period of applying such pesticides by farmers in Sierra Leone and Turkey

\begin{tabular}{|l|l|l|l|l|l|}
\hline Country & Daily & Weekly & Monthly & Yearly & Total \\
\hline $\begin{array}{l}\text { Sierra } \\
\text { Leone }\end{array}$ & 0 & 5 & 45 & 0 & 50 \\
\hline Turkey & 3 & 12 & 35 & 0 & 50 \\
\hline $\begin{array}{l}\text { Sum } \\
\text { TOTAL }\end{array}$ & 3 & 17 & 80 & 0 & 100 \\
\hline
\end{tabular}

Figure 4.18 percentage of respondents applying various pesticides at different period in Bombali District (Sierra Leone) and Beypazari District (Turkey). However, out of the total percentage of farmers (50) interviewed in Bombali District (Sierra Leone), (0\%) applied pesticides daily, (5\%) applied weekly while (45\%) applied monthly. however, no farmer interviewed in Sierra Leone (Bombali District) applied pesticides yearly. Similarly for Turkey (Beypazari District), (3\%) of the farmers applied pesticides daily, (12\%) applied weekly while (35\%) applied monthly. No farmer interviewed in Beypazari District (Turkey) applied pesticides year.

From the data, vegetable farmers in Sierra Leone (Bombali District) applied pesticides monthly than Beypazari District (Turkey).

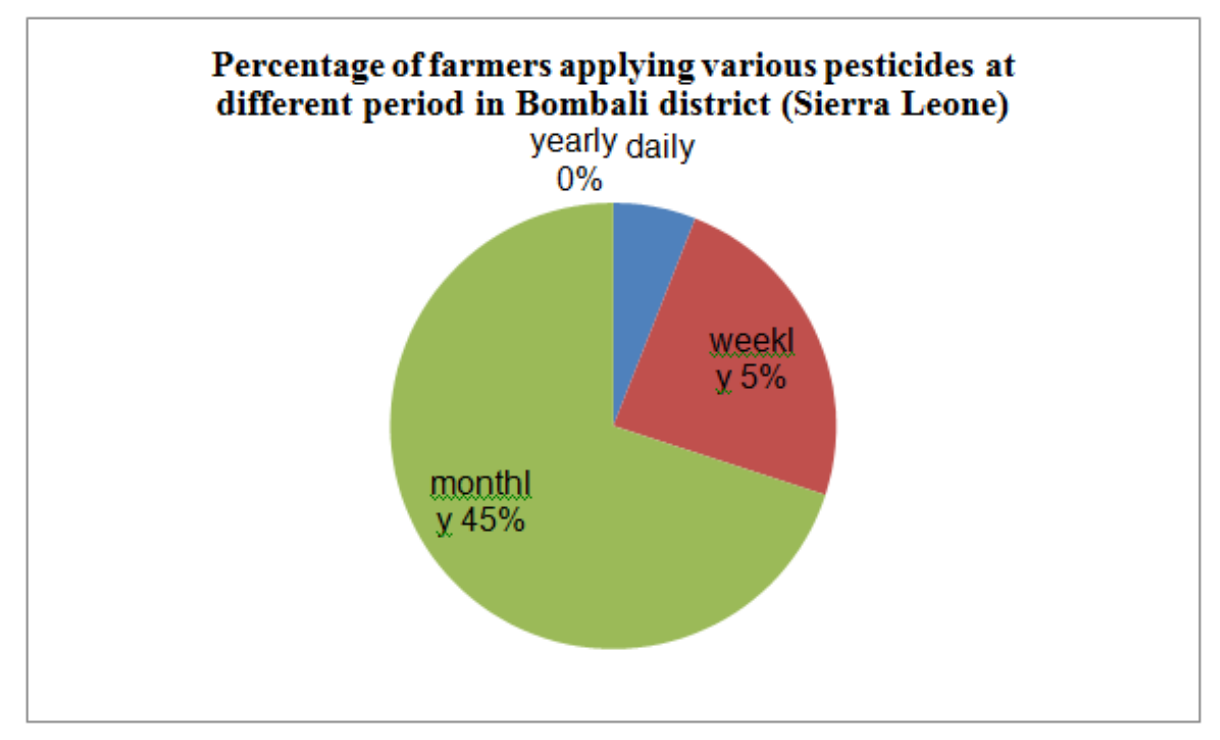




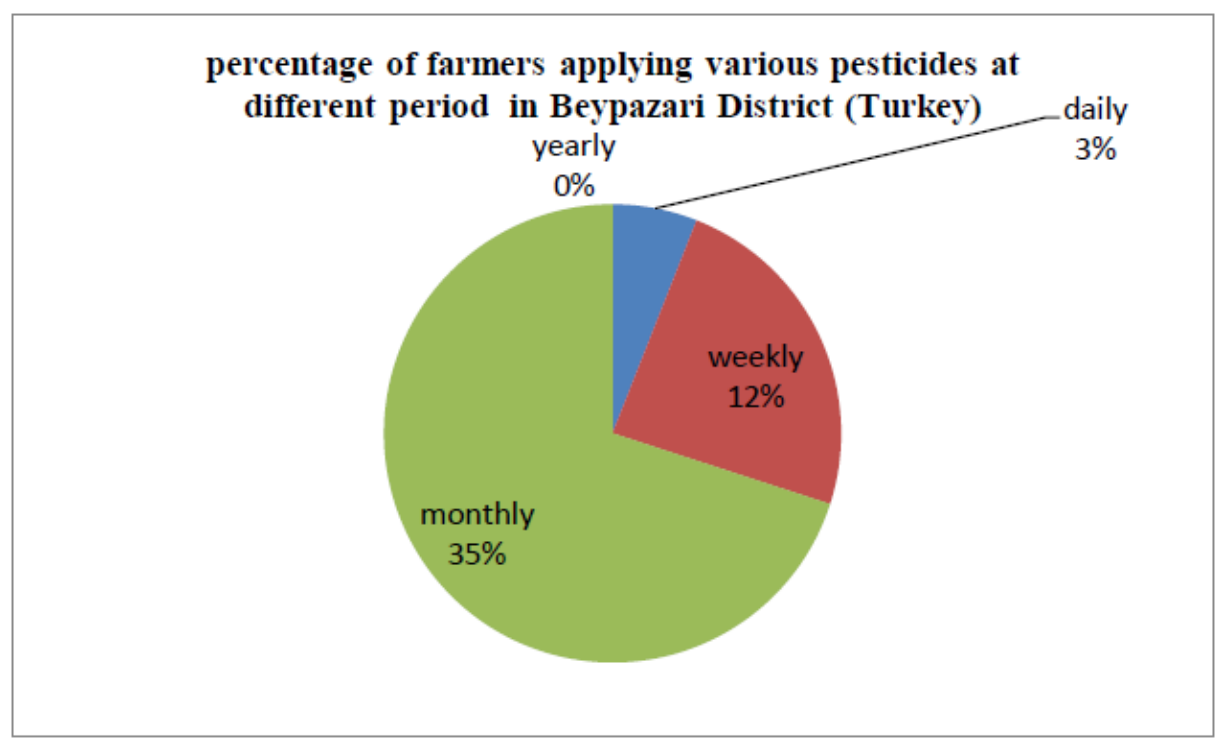

Figure 4.18 above represent percentage of respondents applying various pesticides at different period in Bombali District (Sierra Leone) and Beypazari District (Turkey)

Level of agreement regarding the effect of pesticides on the following categories

Table 4.20 Various negative impacts of using pesticides encountered by farmers in Sierra Leone and Turkey

\begin{tabular}{|l|l|l|l|l|l|}
\hline Country & $\begin{array}{l}\text { Affect } \\
\text { humans } \\
\text { health }\end{array}$ & $\begin{array}{l}\text { Affect } \\
\text { livestock }\end{array}$ & $\begin{array}{l}\text { Affect } \\
\text { marine } \\
\text { resources }\end{array}$ & Affect crops & Total \\
\hline $\begin{array}{l}\text { Sierra } \\
\text { Leone }\end{array}$ & 20 & 10 & 9 & 11 & 50 \\
\hline Turkey & 25 & 10 & 5 & 10 & 50 \\
\hline $\begin{array}{l}\text { Sum } \\
\text { TOTAL }\end{array}$ & 45 & 20 & 14 & 21 & 100 \\
\hline
\end{tabular}

Figure 4.19 shows the various negative effects of pesticides encountered by farmers in Sierra Leone (Bombali District) and Turkey (Beypazari District). Out of the fifty (50) vegetable farmers interviewed in Sierra Leone (Bombali District), twenty (20) of the farmers interviewed responded on the human health effect, ten (10) of them responded on the effect of livestock, nine 
(9) on the effect of marine resources, while eleven (11) of the responded on the effect it has on crop production. Similarly for Turkey (Beypazari District), out of the fifty (50) vegetable farmers interviewed, twenty five (25) of the vegetable farmers elaborated on the human health effect, fifteen (15) on the effect of livestock, thirteen (13) lamented on the effect of marine resources while twelve (12) of the farmers mentioned the effect it has on crop production respectively.

From the data, vegetable farmers in Beypazari District(Turkey) agreed more that pesticides have negative affect human health compare to Sierra Leone (Bombali district).
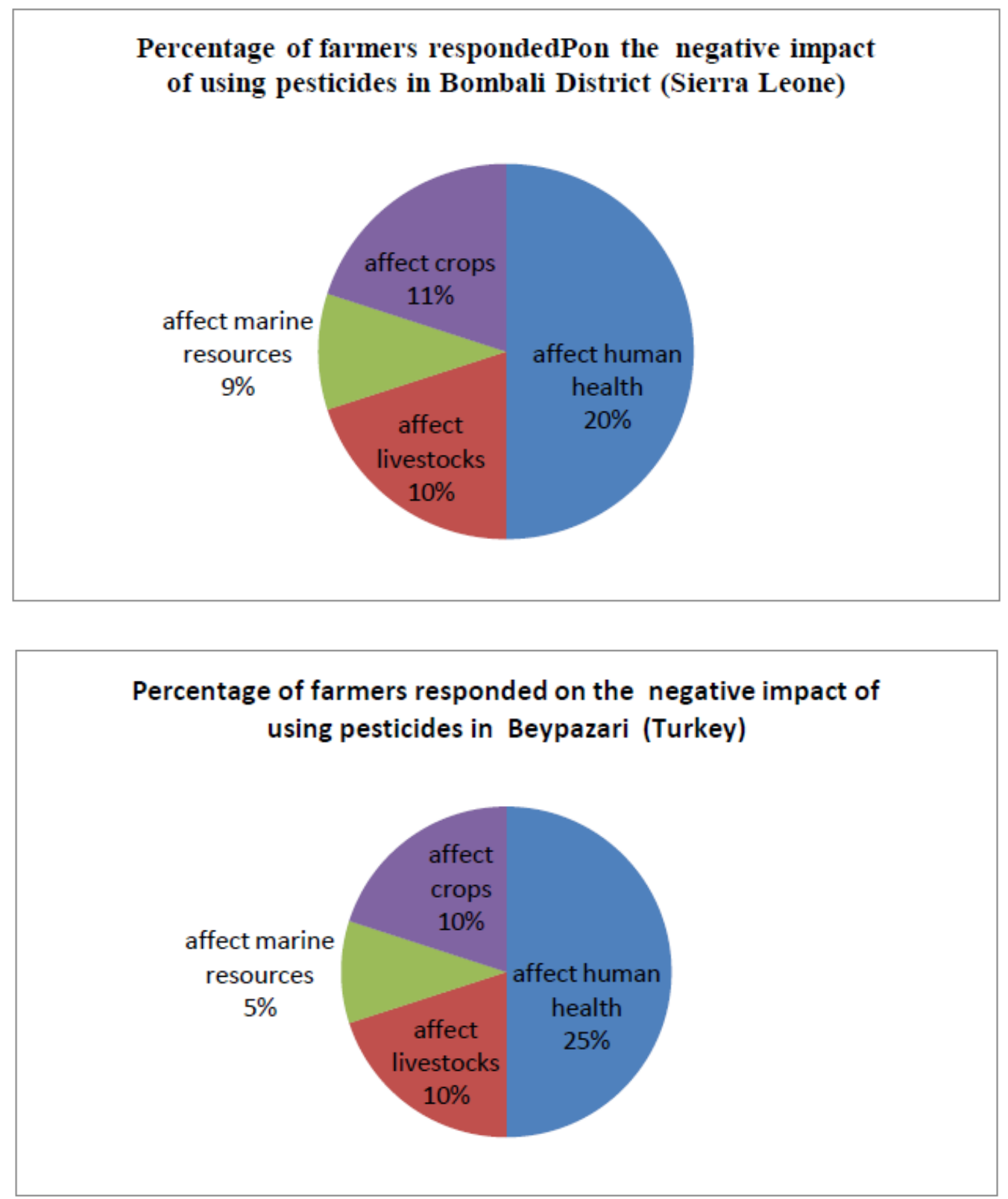
Figure 4.19 above represent Percentage of respondents' responded base on the negative impact of using pesticides in Bombali District (Sierra Leone) and Beypazari District (Turkey)

Farmers' practices on pesticides.

Table 4.21 Farm practice on pesticides

\begin{tabular}{|l|l|l|l|l|l|l|}
\hline Country & \multicolumn{2}{|l|}{$\begin{array}{l}\text { Mixing } \\
\text { Pesticides }\end{array}$} & \multicolumn{2}{l|}{$\begin{array}{l}\text { Use Personal } \\
\text { Protective }\end{array}$} & \multicolumn{2}{l|}{$\begin{array}{l}\text { Read Pesticides } \\
\text { Manual }\end{array}$} \\
\hline & Yes & No & Yes & No & Yes & No \\
\hline $\begin{array}{l}\text { Sierra } \\
\text { Leone }\end{array}$ & 45 & 5 & 45 & 5 & 20 & 30 \\
\hline Turkey & 48 & 2 & 40 & 10 & 47 & 3 \\
\hline $\begin{array}{l}\text { Sum } \\
\text { TOTAL }\end{array}$ & 93 & 7 & 85 & 15 & 67 & 33 \\
\hline
\end{tabular}

Figure 4.20 Percentage of farmers practiced mixing and non-mixing of pesticides in Bombali District (Sierra Leone) and Beypazari District (Turkey). However, out of the percentage of the targeted farmers, (50) in Bombali District, (45\%) of the farmers practiced mixing of pesticides while (5\%) were not. Likewise Turkey (Beypazari District), (48\%) of the farmers interviewed yes for the mixing of pesticides while $(2 \%)$ say no to it.

From the data, vegetable farmers in Turkey (Beypazari District) practiced more mixing pesticides than Vegetable farmers in Sierra Leone (Bombali District). 

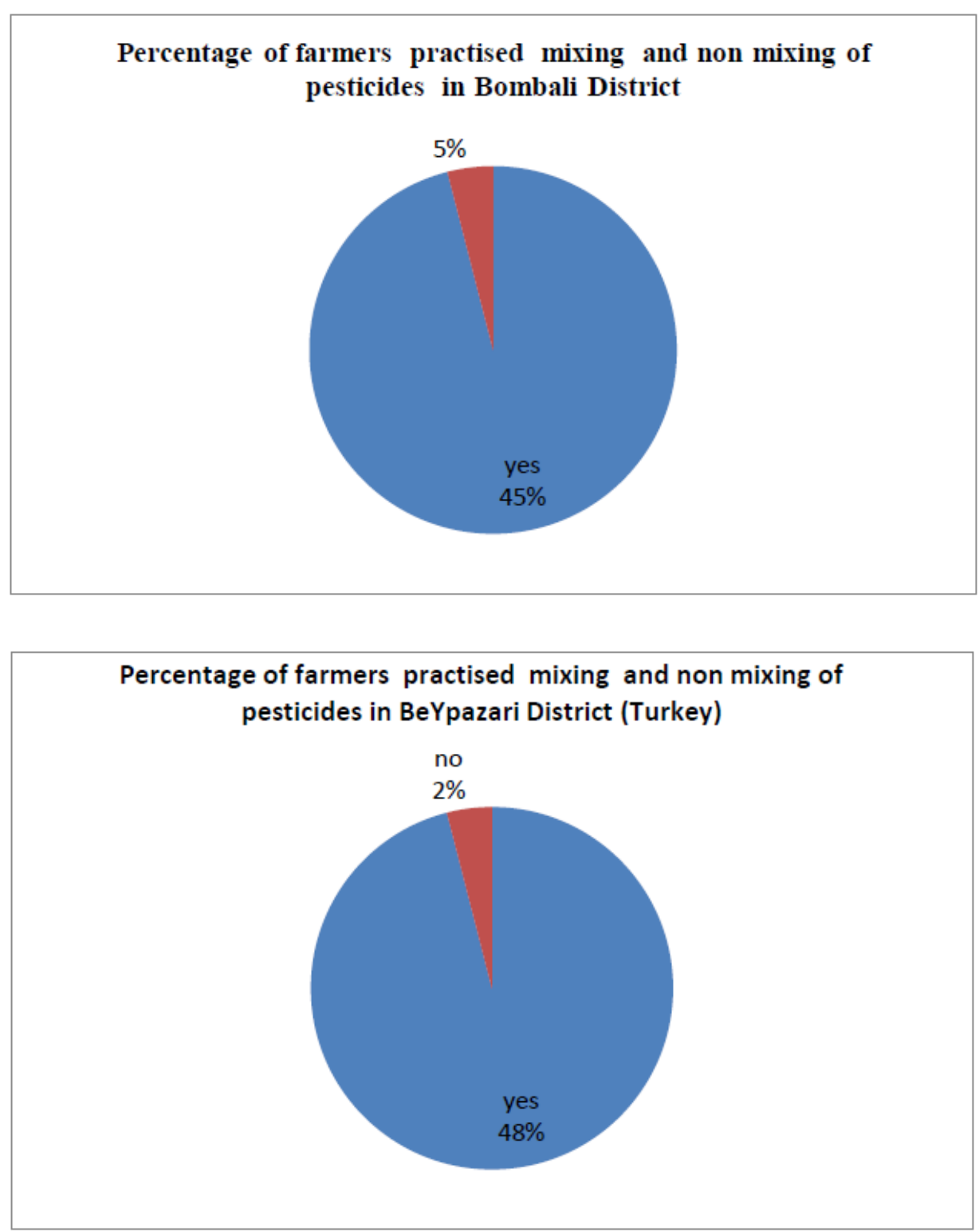

Figure 4.20 above represent Percentage of farmers practiced mixing and non-mixing of pesticides in Bombali District (Sierra Leone) and Beypazari District (Turkey)

Figure 4.21 Percentage of farmers that read pesticides manual and those who were not in Bombali District (Sierra Leone) and Beypazari District (Turkey). In Sierra Leone (Bombali District), out of the (50) farmers interviewed, (20\%) normally read pesticides manual while (30\%) are not. Similarly for Turkey (Beypazari District), (47\%) of the interviewed farmers usually read pesticides manual while (3\%) of them are not. 
From the data, vegetable farmers in Turkey (Beypazari District) read pesticides manual than vegetable farmers in Sierra Leone (Bombali District).

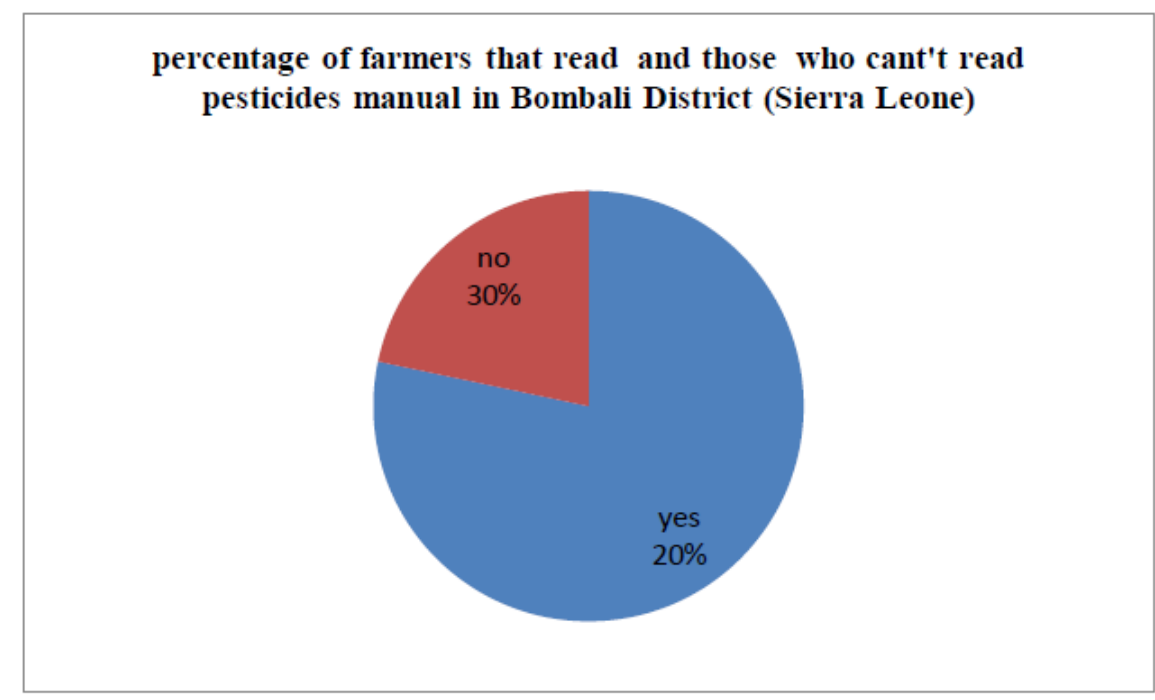

percentage of farmers that read and those who can't read pesticides manual in Beypazari District (Turkey)

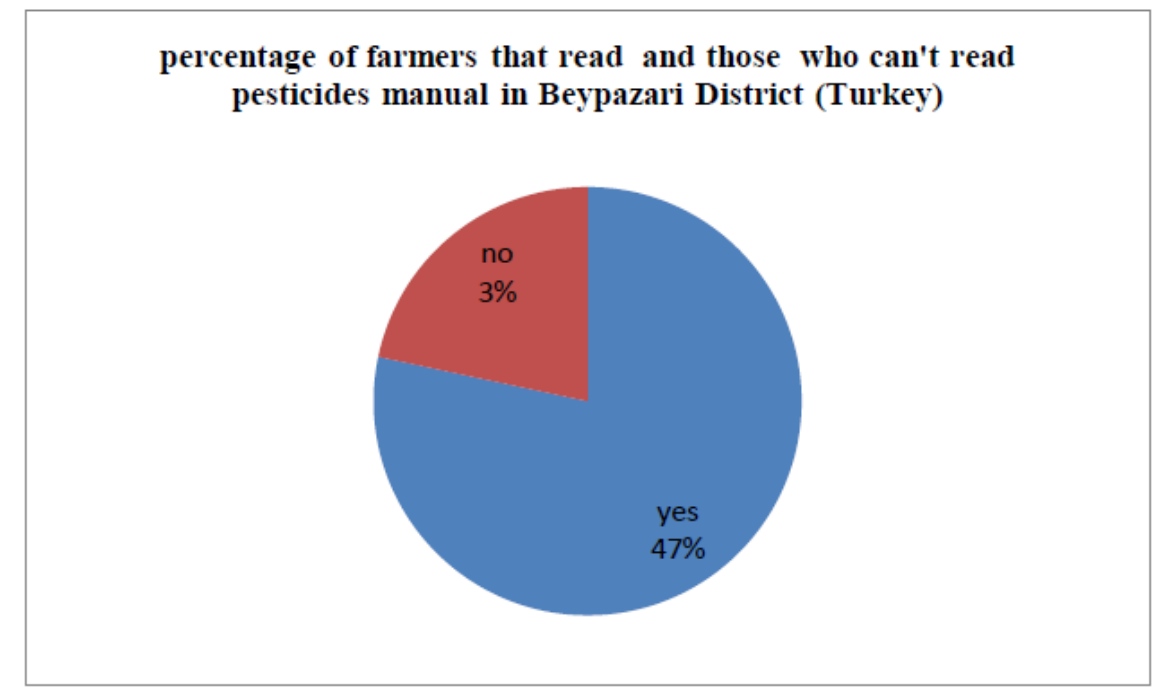

Figure 4.21 above Percentage of farmers that read pesticides manual and those who were not in Bombali District (Sierra Leone) and Beypazari District (Turkey) 
The Perception of farmers on the causes of change in climate in pest control activities

\section{Heard about the expression climate change}

Table 4.22 Hearing about the expression of climate change

\begin{tabular}{|l|l|l|}
\hline Country & \multicolumn{2}{|l|}{ Have you ever heard about the expression climate } \\
& Yes No \\
\hline Sierra Leone & 35.0 & 15.0 \\
\hline Turkey & 40.0 & 10.0 \\
\hline Sum total & 75 & 25 \\
\hline
\end{tabular}

Figure 4.22 Percentage of farmers that heard about climate change and those who are not in Bombali District (Sierra Leone) and Beypazari District (Turkey). In Sierra Leone (Bombali District), out of the targeted (50) farmers that were interviewed, (35\%) have previously heard about climate while (15\%) have never heard about that. Likewise Turkey (Beypazari District), $(40 \%)$ of the farmers interviewed had heard about climate change while (10\%) are not.

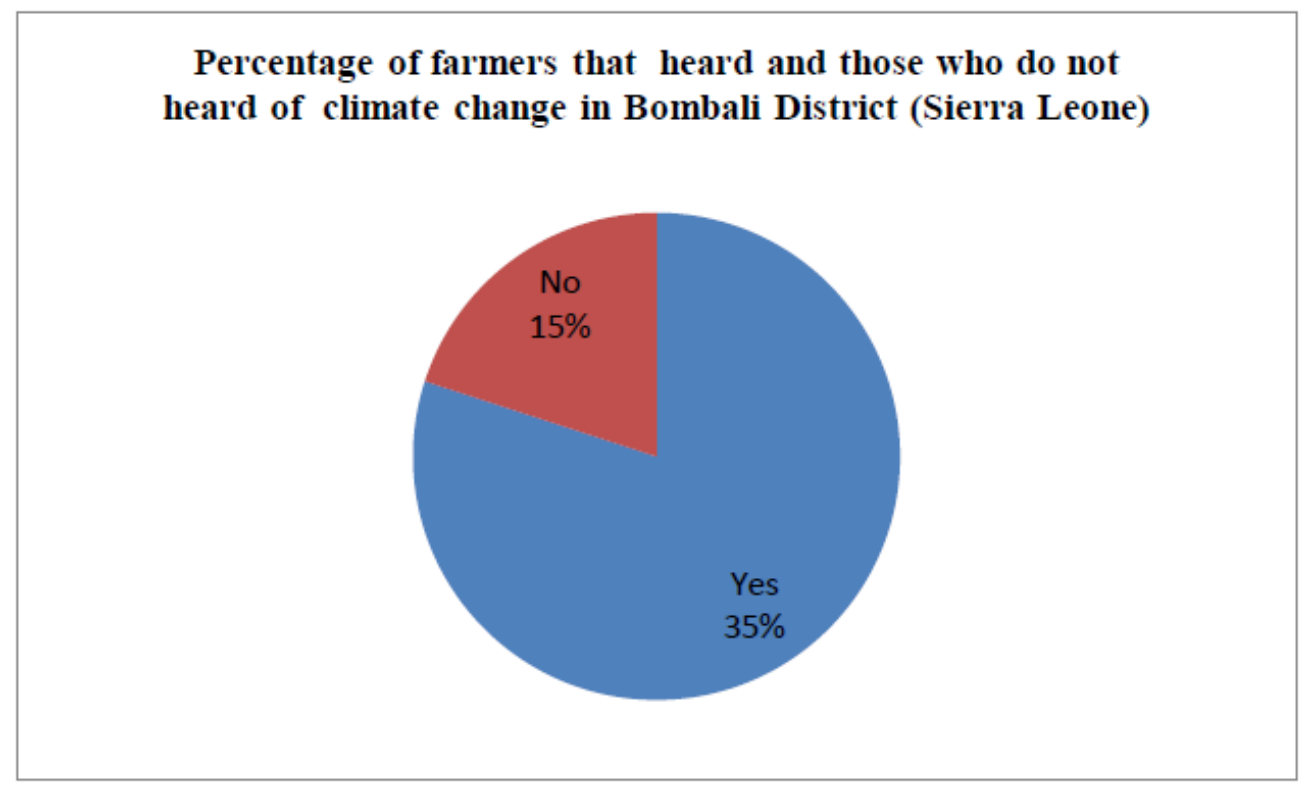


percentage of farmers that heard and those who do not heard of climate change in Beypazari (Turkey)

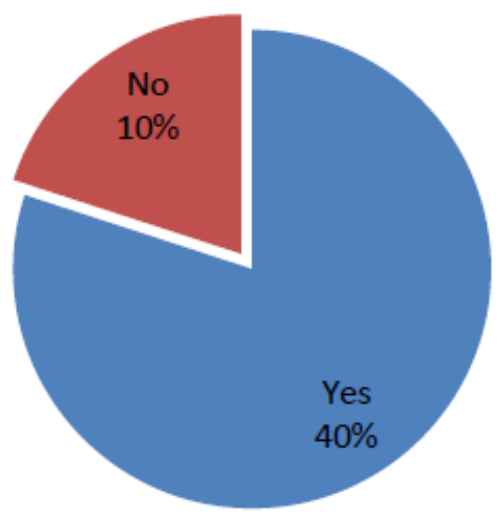

Figure 4.22 above represent Percentage of farmers that heard about climate change and those who are not in Bombali District (Sierra Leone) and Beypazari District (Turkey)

\section{Information about climate change}

Table 4.23 shows the sources of enquiring information for climate change and the belief in climate change as a problem.

\section{Believe that climate change is a problem}

Out of the one hundred (100) vegetable farmers interviewed, fifty (50) of the vegetable farmers in Sierra Leone (Bombali District) believed that climate change is a problem and also fifty (50) in Turkey (Beypazari District) believed that climate change is a problem. 
International Journal of Agriculture and Environmental Research

ISSN: 2455-6939

Volume: 07, Issue: 04 "July-August 2021"

Table 4.23 Sources of enquiring information for climate change and believes in climate change as a problem

\begin{tabular}{|l|l|l|l|l|l|l|l|}
\hline Country & \multicolumn{2}{|l|}{$\begin{array}{l}\text { Source of enquiring information for climate } \\
\text { change }\end{array}$} & \multicolumn{2}{|l|}{$\begin{array}{l}\text { Believe in climate } \\
\text { change as a problem }\end{array}$} \\
\cline { 2 - 8 } & $\begin{array}{l}\text { Agriculture } \\
\text { institution }\end{array}$ & $\begin{array}{l}\text { Mass } \\
\text { media }\end{array}$ & University & $\begin{array}{l}\text { Lead } \\
\text { farmer }\end{array}$ & Yes & No & $\begin{array}{l}\text { Don't } \\
\text { know }\end{array}$ \\
\hline $\begin{array}{l}\text { Sierra } \\
\text { Leone }\end{array}$ & 5 & 40 & 3 & 2 & 50 & 0.0 & 0.0 \\
\hline Turkey & 10 & 30 & 5 & 5 & 50 & 0.0 & 0.0 \\
\hline Total & 15 & 70 & 8 & 7 & 100 & 0.0 & 0.0 \\
\hline
\end{tabular}

Figure 4.23 Percentage of farmers acquired information on climate from various channels in Bombali District (Sierra Leone) and Beypazari District (Turkey). In Sierra Leone (Bombali District), out of the targeted population of farmers of (50), (5\%) of them sourced information about climate change through agricultural institution, (40\%) acquired information through media, (3\%) and (2\%) extracted information on climate change through university and fellow farmers respectively. Similarly for Turkey (Beypazari District), out of the 50 vegetable farmers in interviewed, (10\%) of them access information about climate change through agricultural institution, (30\%) acquired information through media, (5\%) of them through university while (5\%) access information through fellow farmers.

From the data, vegetable farmers in Sierra Leone (Bombali District) acquired more information from media compared to Turkey (Beypazari District). 

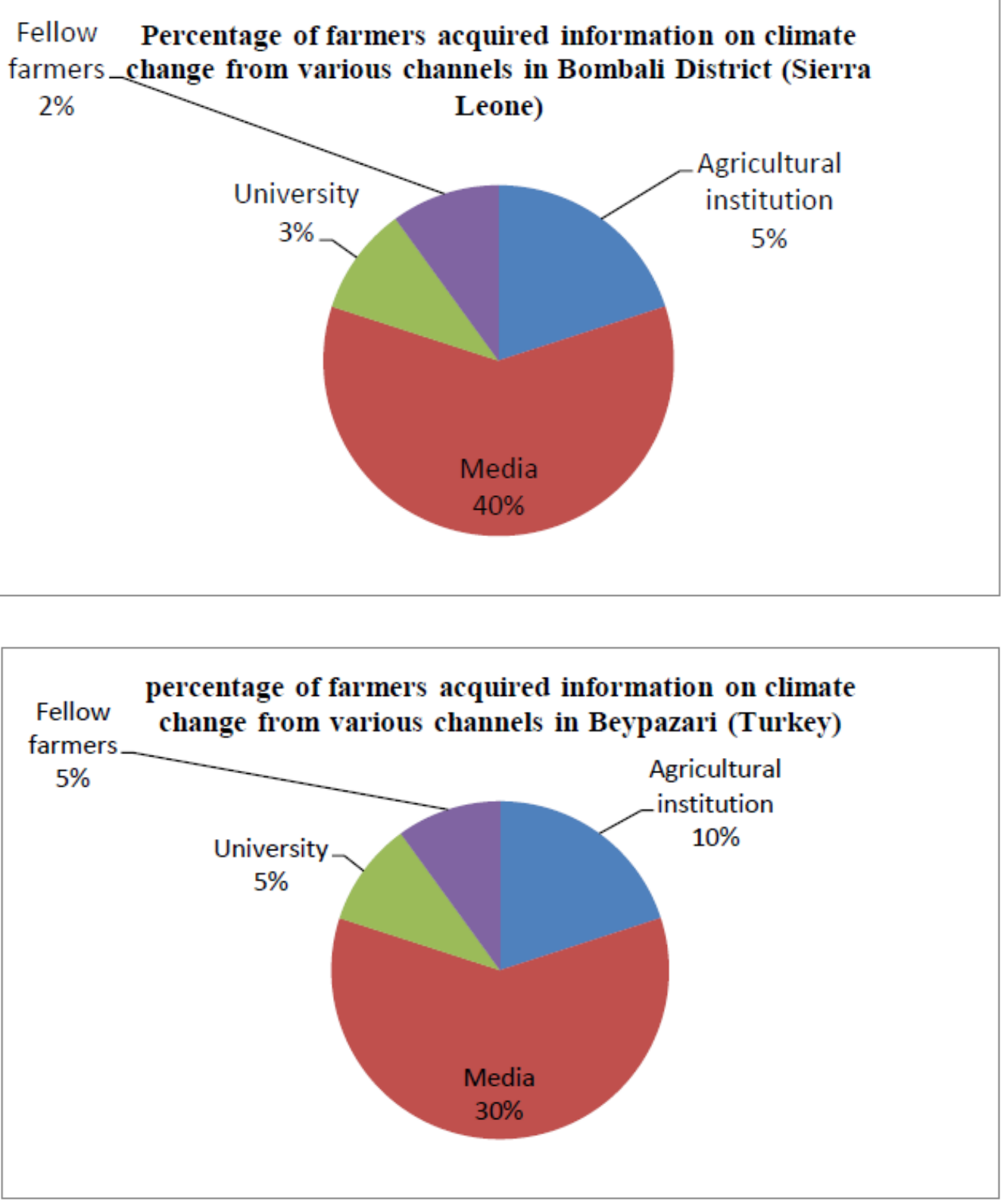

Figure 4.23 above represent Percentage of farmers acquired information on climate from various channels in Bombali District and Beypazari District (Turkey) 


\section{Worry about climate change}

Table 4.24 How much do you worry about climate change

\begin{tabular}{|l|l|l|l|l|l|}
\hline Country & Not at all & Very little & Kind off & Too much & Total \\
\hline $\begin{array}{l}\text { Sierra } \\
\text { Leone }\end{array}$ & 10 & 15 & 15 & 10 & 50 \\
\hline Turkey & 20 & 10 & 10 & 10 & 50 \\
\hline $\begin{array}{l}\text { Sum } \\
\text { TOTAL }\end{array}$ & 30 & 25 & 25 & 20 & 100 \\
\hline
\end{tabular}

Figure 4.24 Percentage of farmers responded with regards their level of worries about climate change in Bombali District (Sierra Leone) and Beypazari district (Turkey). In Sierra Leone (Bombali District), out of the targeted (50) farmers interviewed, (10\%) of the farmers were not worried at all about climate change, (15\%) worried very little, (15\%) have kind off worried while $(10 \%)$ have too much worried about climate change. Likewise Turkey (Beypazari District), $(20 \%)$ of the farmers interviewed were not at all worried about climate change, $(10 \%)$ are very little worried, (10\%) are kind off worried while (10\%) have too much worried about climate change.

From the data, vegetable farmers in Sierra Leone (Bombali District) are more very little or kind of worried about climate change compared to Turkey (Beypazari District). 
percentage of farmers responded base on their level of worries about climate change in Bombali District (Sierra Leone)

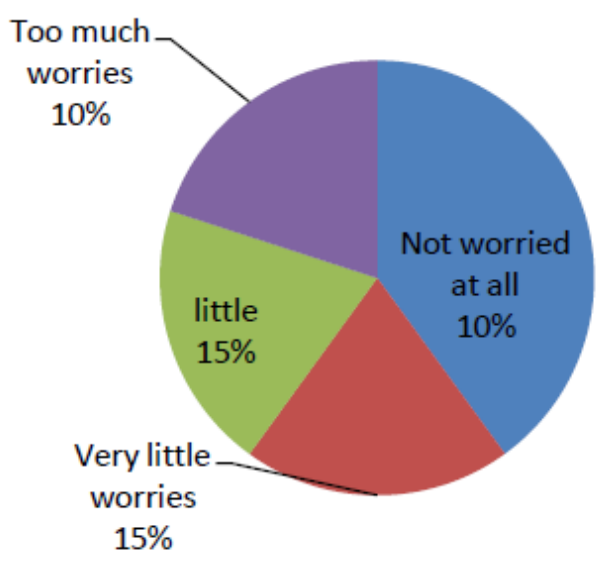

percentage of farmers responded base on their level of worries about climate change in Beypazari (Turkey)

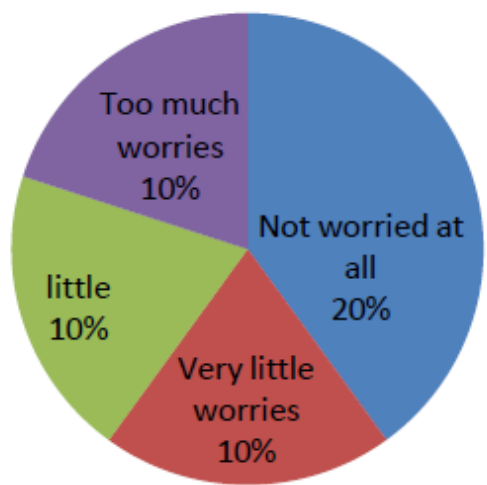

Figure 4.24 above represent Percentage of farmers responded with regards their level of worries about climate change in Bombali District (Sierra Leone) and Beypazari District (Turkey) 
Thinking about in relation with the climate change

Table 4.25 Thinking about in relation with the climate change

\begin{tabular}{|l|l|l|l|l|l|}
\hline Country & $\begin{array}{l}\text { Change in } \\
\text { crop yield }\end{array}$ & $\begin{array}{l}\text { Global } \\
\text { warming }\end{array}$ & Soil erosion & Drought & Total \\
\hline Sierra Leone & 30 & 10 & 5 & 5 & 50 \\
\hline Turkey & 35 & 5 & 5 & 5 & 50 \\
\hline Sum TOTAL & 65 & 15 & 10 & 10 & 100 \\
\hline
\end{tabular}

Figure 4.25 Percentage of farmers base on their thoughts about climate change in Bombali District (Sierra Leone) and Beypazari District (Turkey). out of (50) farmers interviewed in Sierra Leone, (30\%) of them have the feeling of thoughts that climate change may cause change in crop yield, (10\%) deliberated on the causes of global warming, $(5 \%)$ lamented on the causes of soil erosion while (5\%) mentioned that climate change may cause drought. Similarly for Turkey (Beypazari District), an estimated percentage of (35\%) of farmers interviewed deliberated on change of crop yield as a result of climate change, $(5 \%)$ emphasized on global warming due climate change, $(5 \%)$ lamented on soil erosion while $(5 \%)$ deliberated on drought as a result of climate change.

From the data, vegetable farmers in Turkey (Beypazari District) thinks that change in crop yield in relation to climate change more compare to Sierra Leone (Bombali District) 

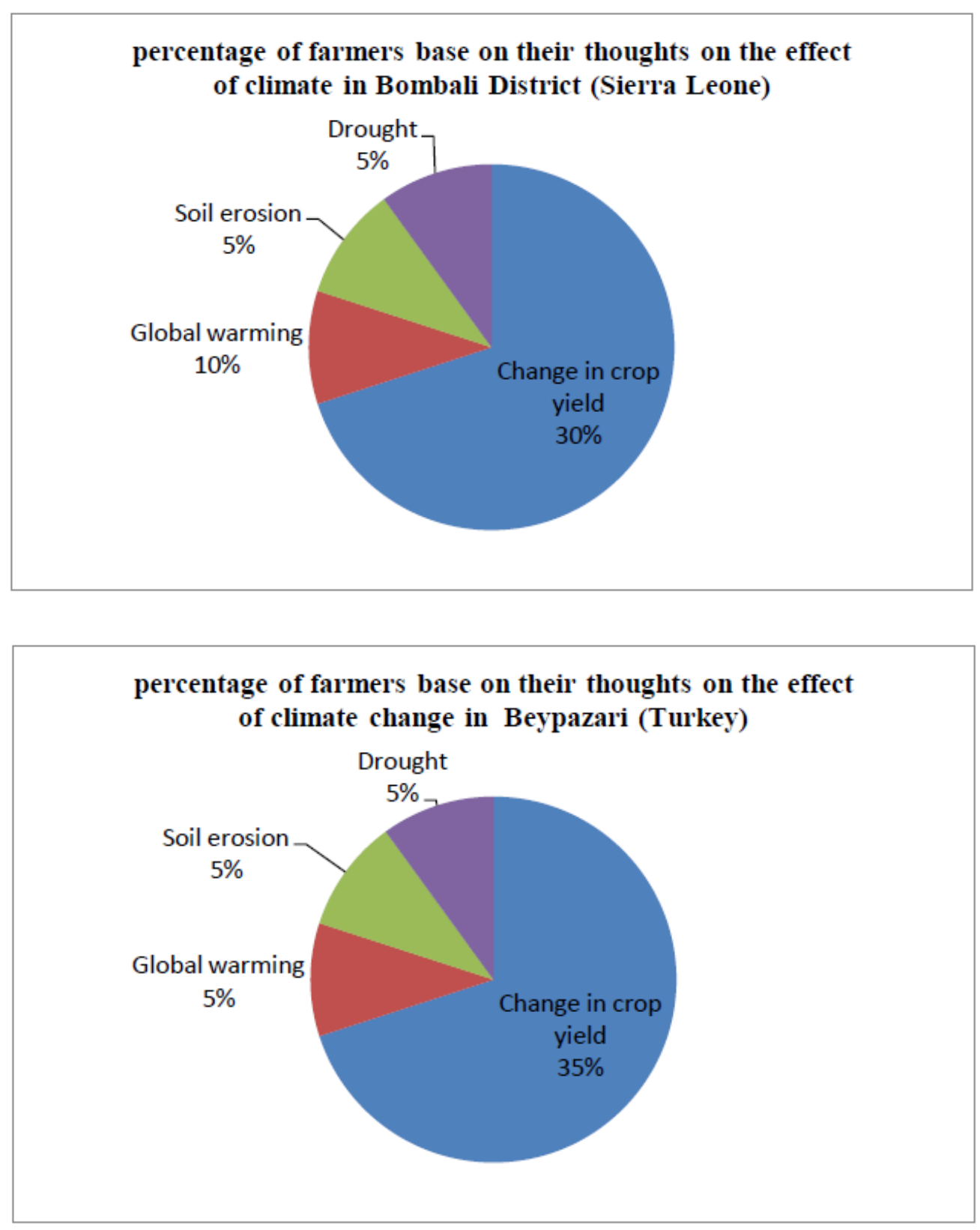

Figure 4.25 above represent Percentage of farmers' base on their thoughts about climate change in Bombali District (Sierra Leone) and Beypazari District (Turkey) 
Believe that climate change is due to human activities

Table 4.26 Believe that climate change is due to human activities

\begin{tabular}{|l|l|l|l|}
\hline Country & Yes & No & Total \\
\hline $\begin{array}{l}\text { Sierra } \\
\text { Leone }\end{array}$ & 30 & 20 & 50 \\
\hline Turkey & 40 & 10 & 50 \\
\hline $\begin{array}{l}\text { Sum } \\
\text { TOTAL }\end{array}$ & 70 & 30 & 100 \\
\hline
\end{tabular}

Figure 4.26 Percentage of farmers had the believe and those who are not that climate change is due to human activities in Bombali District (Sierra Leone) and Beypazari District (Turkey). In Sierra Leone (Bombali District), out of the (50) farmers interviewed in Sierra Leone (Bombali District), (30\%) of the farmers believe that climate change is cause by human activities while (20\%) are not. Similarly for Turkey (Beypazari District), out of the (50) farmers targeted, (40\%) of them believe that climate change is cause by numerous human activities while (10\%) are not.

From the data, vegetable farmers in Turkey (Beypazari District) believe more that climate change is cause by the numerous human activities compared to Sierra Leone (Bombali District).

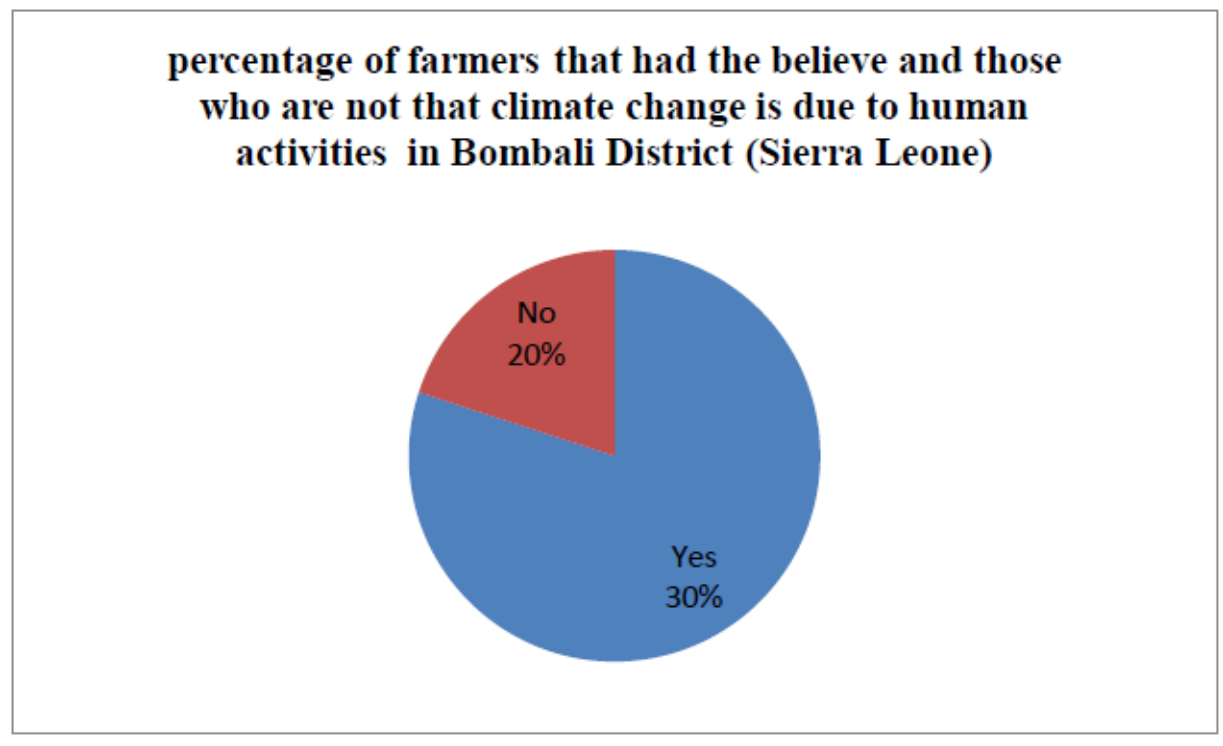


percentage of farmers that had the believe and those who are not that climate change is due to human activities in Beypazari District (Turkey)

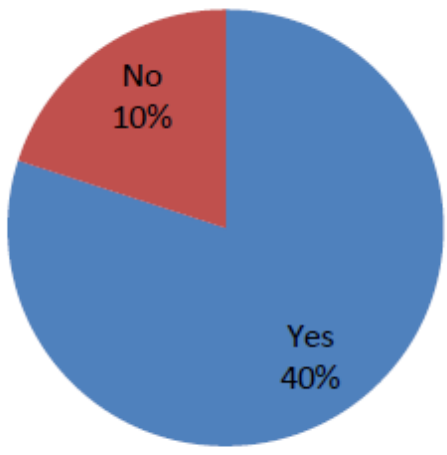

Figure 4.26 above represent Percentage of farmers had the believe and those who are, not that climate change is due to human activities in Bombali District (Sierra Leone) and Beypaqzari District (Turkey)

Reasons for climate change

Table 4.27 reasons for the climate change

\begin{tabular}{|l|l|l|l|l|l|l|}
\hline \multirow{3}{*}{ Country } & \multicolumn{5}{|l|}{ Reasons for the climate change } \\
\cline { 2 - 7 } & \multicolumn{2}{|l|}{ Ozone Layer Damage } & \multicolumn{2}{l|}{ Air Pollution } & \multicolumn{2}{l|}{ Toxic Waste } \\
\cline { 2 - 7 } & Yes & No & Yes & No & Yes & No \\
\hline Sierra & 20.0 & 30.0 & 40.0 & 10.0 & 35 & 15 \\
Leone & & & & & & \\
\hline Turkey & 30.0 & 20.0 & 45.0 & 5.0 & 40 & 10 \\
\hline Total & 50 & 50.0 & 85 & 15 & 75 & 25 \\
\hline
\end{tabular}

Figure 4.27 Percentage of farmers respondents base on the various reason for climate change in Bombali District (Sierra Leone) and Beypazari District (Turkey). considering the percentage of 
targeted farmers in Sierra Leone (Bombali District) out of the (50), (30\%) of the farmers says yes ozone layer damage as a main cause of climate change and (20\%) says no, (40\%) says yes on air pollution as a cause while (10\%) says no, on toxic waste $(35 \%)$ says yes and $(15 \%)$ says no. similarly for Turkey (Beypazari District), out of the (50) farmers interviewed, (30\%) says yes on ozone layer damage as a cause of climate change and (20\%) says no ,(45\%) says yes on air pollution while (5\%) says no and on toxic waste (40\%) says yes and (10\%) says no.

From the data, majority of the vegetable farmers in Turkey (Beypazari District) mentioned ozone layer damage and air pollution are the main reason to climate change compare to Sierra Leone (Bombali District).

percentage of farmers responded for various reasons of climate change in Bombali District (Sierra Leone)

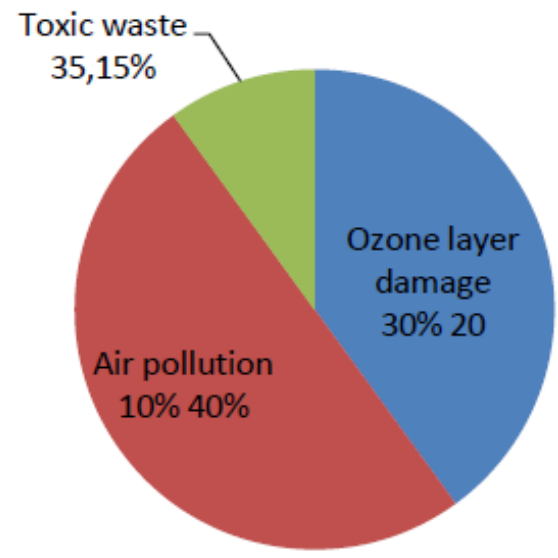




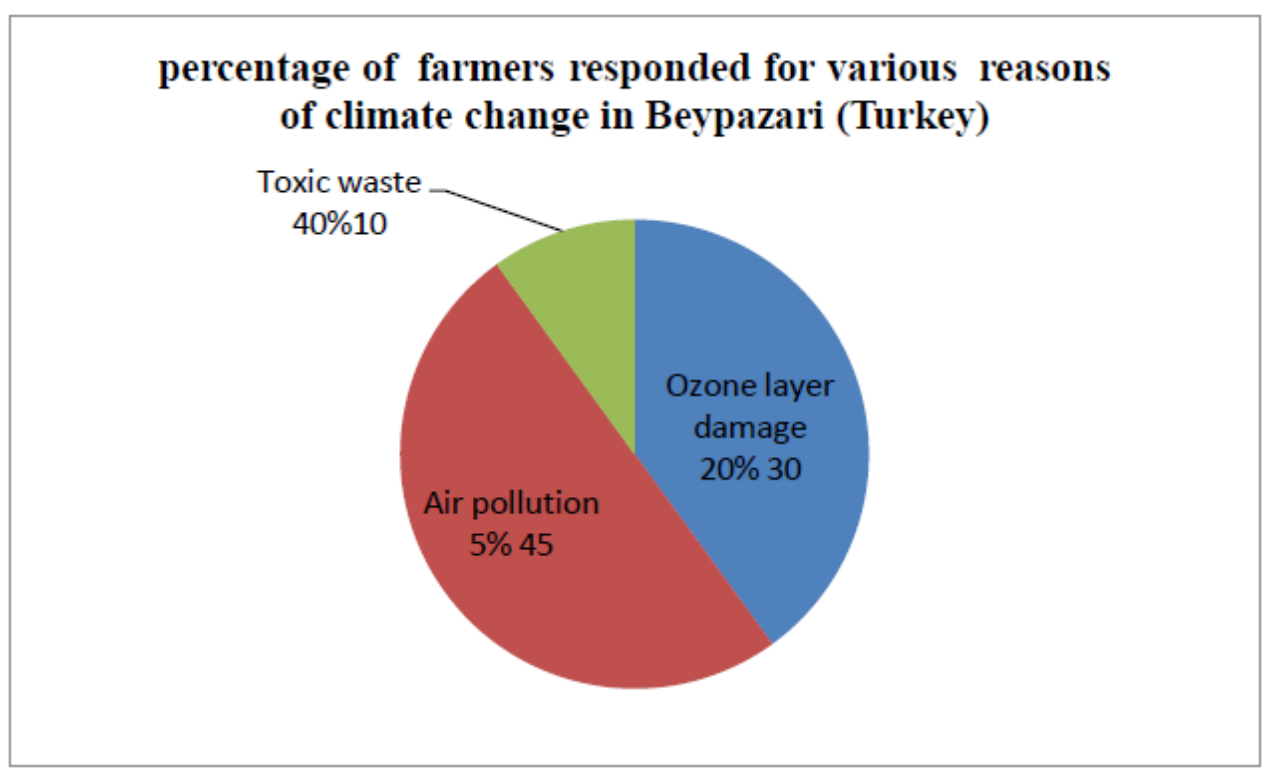

Figure 4.27 above represents Percentage of farmers' responded base on the various reasons for climate change in Bombali District (Sierra Leone) and Beypazari District (Turkey)

\section{DISCUSSION AND CONCLUSIONS}

Overall objective of this study was the effect of climate change on vegetable farmers in pest control decisions (Case study Sierra Leone (Bombali district) and Turkey (Beypazari district)) with specific objectives such as, to identify the new situation caused by climate change in pest controls activities, to identify the factors affecting farmer decisions making process on pest control and the Perception of vegetable farmers on the causes of change in climate in pest control activities. The study was limited to Bombali district, Sierra Leone, and Beypazari district, Turkey. Data collection mainly targeted household heads.

A survey research design was adopted based on which a verified questionnaire was developed. The population for this study is both male and female household heads in these chiefdoms. The size of the sample for this study was determined by purposive sampling. The sampling technique used to carry out the selection of the respondents is two stages. Stage one was a purposive selection of the project areas (areas mostly vegetable production). Stage two was respondent selection. Purposive sample technique was used in the selection of household heads for the study. The information was collected by using a survey; the questionnaire was administered by the researcher himself and three (3) enumerator to the vegetable farmers.

The data collected was entered and analyzed by simple descriptive analysis by using SPSS. 
International Journal of Agriculture and Environmental Research

ISSN: 2455-6939

Volume: 07, Issue: 04 "July-August 2021"

From the findings of this study include. There are more Male household head than female household, from the data, this shows that there are more household head in Beypazari District (Turkey) than Bombali District (Sierra Leone).

an majority of the vegetable farmers are within the age brackets of (39-48) years this presents the active farmers in vegetable production, seventy $(70 \%)$ of the respondents were married, from the data, there are more married vegetable farmers in Turkey (Beypazari District) than Sierra Leone (Bombali District) and also there are more divorced vegetable farmers in Sierra Leone (Bombali District) than Turkey (Beypazari District) an average of twenty two (22\%) of the respondents do not attended school, also (93\%) of them were household heads, the household size for majority of the vegetable farmers is between six (6) people, from the findings the household heads income for Turkey (Beypazari District) is between 5000tl-10000tl and for Sierra Leone (Bombali District) is between le300,000-le500,000.

From the finding of the study, a large number of the respondent in Turkey (Beypazari District) have received pest management training and only few Sierra Leone (Bombali District) vegetable farmer have received pest management training, and the majority received training on the chemical method of pest control.

From the finding, the majority of the vegetable farmers practice crop rotation, and in Sierra Leone (Bombali District) is rice and groundnut and for Turkey (Beypazari District) is rice and maize.

According to the study low growing season is the new weather conditions that have affected farmers pest control activates the most at their current location and most of the farmers practice inter cropping and rice and maize are the major crops they use for inter cropping.

The study revealed majority of the farmers use pesticides and these pesticides are herbicides and insecticides and they only use such chemicals monthly.

According to the studies, pesticides affected human health.

The study revealed the farm practices of vegetable farmers are mixing pesticides, use Personal Protective and Read Pesticides Manual According to the findings from the study, major of the vegetable farmers in Turkey (Beypazari District) and Sierra Leone (Bombali District) have heard about climate change from mass media and they believe in climate change as a problem

From the finding, the majority of the farmers not at all worried about climate change, and the first thing they think relation to change in climate is change in crop yield. 
The study revealed the farmers' believed that climate change is due to human activities and the reason is air pollution

The following conclusions were drawn from the study:

Male household heads are more than female household head.

Most of the household head were within the age bracket of (39-49) years, these shows that there are more youth engaged in vegetable production. since most of them were married and tend to adopt adequate knowledge on the effect of climate change in their environment and how to control pest activities in their vegetable farms. None educated household head were very few among. The household size is six (6) people which adopt adequate knowledge on the effect of change in climate on vegetable farmers in pest control decisions. From the study the respondent main income is vegetable farming.

From the data, the household head preference is adequate knowledge on the effect of climate change in their environment.

\section{Recommendations}

The following recommendations were drawn from the study;

1. Vegetable farmers in Sierra Leone should receive training on pest management. In addition, other alternatives for the method of pest control should be made available to rural households to avoid the effect of the use of chemicals.

2. The study recommends that support is needed to promote higher production of crops.

3. According to what the study revealed, low growing season affected farmers most due to climate change, collaborative efforts from stakeholders in Turkey and Sierra Leone to create adequate awareness on the use of pesticide.

\section{ACKNOWLEDGEMENTS}

Sincere thanks to all respondents who contributed to this study, sharing their knowledge and entrusting me in the process. Special thanks to Prof. Dr. Mevlut Emekci my supervisor and Cosupervisor Prof. Dr. Bülent Gülçubuk for being my 'conversation partner' and steering me ever more to be an entomologist.

A special thanks to my parent Mr. Alex. M. Kargbo and Aminata Paulina Kargbo, Ryt Colonel 
International Journal of Agriculture and Environmental Research

ISSN: 2455-6939

Volume: 07, Issue: 04 "July-August 2021"

Paul Koroma and family, Dr. Ali Patrick Koroma and family, Dr. Philip J. Kanu and family, miss Abie Koroma my two lovely sisters Agness Kargbo and Patricia Kargbo for making it all possible and being there when I needed it most and for their patience and undying support; and last, but certainly not least, special thanks to my lovely grandmother Janet B Koroma for keep checking on me and my late grandfather, Ali Paul Koroma.

Notwithstanding, I may like to extend my sincere thanks to Dr. Sait Ertürk (Director of the Institute of Plant Protection Central Research Institute, MAFF), Esin Korkmaz (Director of Agriculture and Forestry of Beypazari District, MAFF), for organized the interviews with the farmers in Beypazari District, Turkey and also Mohamed Kargbo and team for organized the interview with farmer in Bombali District Sierra Leone.

\section{REFERENCES}

Anton Eitzinger \& Claudia R. Binder \& Markus A. Meyer (2016:507). Risk perception and decision-making: do farmers consider risks from climate change.

Abril, A, Oliveras, J and Gomez, C (2008:10). Effect of temperature on the development and survival of the Argentine ant, Linepithema humile. Journal of Insect Science 10: 97.

Anonymous, 2013. http://www.saveblueplanet.com/effects of global warming.html.

Abolmaaty, S. M.; Khalil, A. A. and Amna, M. H. (2011:55) Using degree- day unit accumulation to predict potato tubeworm incidence under climate change conditions in Egypt. Nat. Sci., 9 (4): 156-160.

Asres Elias et al. (2013:60). Effect of Agricultural Extension Program on Smallholders Farm Productivity: Evidence from Three Peasant Associations in the Highlands of Ethiopia, Journal of Agricultural Science vol.5 No.8

Asfaw, S., Shiferaw, B., Simtowe, F., \& Lipper, L. (2012:280). Impact of Modern Agricultural Technologies on Smallholder Welfare: Evidence from Tanzania and Ethiopia. Food policy. http://dx.doi.org/10.1016/j.foodpol.

Ashraf, N., X. Giné, and D. Karl an. (2009:4). "Finding missing markets and a disturbing epilogue. Evidence from an export crop adoption and marketing intervention in Kenya. American Journal of Agricultural Economics.

Bakare A. S. (2013:20), an econometric analysis of sustainable agriculture and rural development in Nigeria, A Vector Autoregressive Approach (VAR). Journal of 
International Journal of Agriculture and Environmental Research

ISSN: 2455-6939

Volume: 07, Issue: 04 "July-August 2021"

Agricultural Economics and Development.

Banihashemi, S.A. (2011, 24).The Role of Communication to Improve Organizational Process. European Journal of Humanities and Social Sciences. Retrieved from http://www.journalsbank.com/ejhss.htm

Bihon Kassa Abrha (2015:28). Factors affecting agricultural production in the Tigray region, northern Ethiopia.

Coomes, O.T. \& N. Ban (2004:58). Cultivated plant species diversity in home gardens of an Amazonian peasant village in northeastern Peru. Economic Botany.

Dr. Ferlal Örs (2010:4).The contribution of communication to rural development, n Fourth International Conference on Business, Management, and Economics.

Edwards, L. (2001: 40-71). Globalization and the Skills bias of Occupational Employment in South Africa. South African Journal of Economics, vol. 69, no. 1

Egwu, Emeka Williams (2016:56).Communication and adoption behavour of information technology by rural farmers in ebonyi state. Department of Agricultural Economics Management and Extension, Ebonyi State University, Abakaliki, Nigeria.

FAO. (2009: 17-20). Proceedings Mekong Sub-Regional Workshop on Linking Farmers with markets: Intermediation models, policy, and networking.

FAO (2009: 34). The State of Agricultural Commodity Markets. Tech. Rep., Food and Agriculture Organization of the United Nations, Paris.

Garlick, Robert (2012:106). Academic Peer Effects with Different Group Assignment Policies. of Michigan mimeo.

Kondinya Ayyogari, Palash Sidhya and M.K. Pandit ( 2014:143) Impact of Climate Change on Vegetable Cultivation - A Review Department of Vegetable Crops, Bidhan Chandra Krishi Viswavidyalaya, Mohanpur, West-Bengal, India. International Journal of Agriculture, Environment \& Biotechnology IJAEB:

Mohammad Rezaei, Dariush Hayati, Zohreh Rafiee (2014:495). Factors affecting on farmers' attitudes towards sustainable Environmental effects of integrated pest management (A Case Study of pistachio growers in Kerman province) Journal of Middle East Applied Science and Technology (JMEAST). 
Marion Robert \& Alban Thomas \& Jacques-Eric Bergez (2016:2). Processes of adaptation in farm decision-making models. A review.

Meredith T. Niles Nathaniel D. Mueller (2016:133). Farmer perceptions of climate change: Associations with observed temperature and precipitation trends, irrigation, and climate beliefs

Mohammad Aslam Ansari, Sharad Joshi, Rupan Raghuvanshi (2018:85). Understanding farmers perceptions about climate change: a study in a North Indian State. Advances in Agriculture and Environmental Science: Open Access

Nigel R. Andrew and Sarah J. Hill (2017:198). Effect of Climate Change on Insect Pest Management. See discussions, stats, and author profiles for this publication at: https://www.researchgate.net/publication/319443943

Surendra K. Dara (2019:1). The New Integrated Pest Management Paradigm for the Modern Age. Division of Agriculture and Natural Resources, University of California Cooperative Extension, San Luis Obispo, CA 93401 (skdara@ ucdavis.edu) 